\title{
A COMPARATIVE ANALYSIS OF MULTIDIMENSIONAL POVERTY IN SUDAN AND SOUTH SUDAN
}

\author{
Paola Ballon ${ }^{1} \quad$ Jean-Yves Duclos ${ }^{2}$
}

\begin{abstract}
This paper assesses multidimensional poverty in Sudan and South Sudan. We use the National Baseline Household Surveys of 2009 to measure poverty incidence in education, consumption, access to public assets and possession of private assets across these two countries. We differentiate between children aged 6 to 14 years and adults aged 15 years or older. We apply a counting method for measuring multidimensional poverty at the individual level and perform dominance tests to check for the robustness of the poverty comparisons. Our findings show regional and sub-population differences in the unidimensional and multidimensional poverty status of people in both countries. Poverty in Sudan is generally less severe than in South Sudan, with a pattern showing i) lesser unidimensional incidence of poverty, ii) lower multidimensional poverty indices and prevalence, but similar breadth, both for adults and children. This pattern also points towards Khartoum and Western Equatoria as the states with the least poverty, and Northern Darfur, and Warap as the states with the greatest poverty, both for adults and children, in Sudan and South Sudan, respectively. Policy intended at reducing poverty in each of the two countries should recognize the poverty profile differences across age groups, geographical areas and dimensions.
\end{abstract}

Keywords: Multidimensional poverty, Counting method, Poverty indices, Poverty dominance, Deprivation, Multiple correspondence analysis, South Sudan, Sudan.

${ }^{1}$ University of Oxford, U.K. Email:paola.m.ballon@gmail.com

${ }^{2}$ Laval University, Quebec, Canada. Email: jean-yves.duclos@ecn.ulaval.ca. 


\section{Introduction}

From its independence in 1956, Sudan's road to economic and human development has been hampered by internal conflicts that have undermined security and governance. Since 2011, Sudan had to adjust to a large economic shock caused by the loss of the $70 \%$ of the oil revenue due to the secession of South Sudan. Currently, the agriculture and livestock sectors play a strategic role in wealth generation as they account for $40 \%$ of the country's GDP. Sudan remains a highly indebted country as most of its external debt stock is in arrears. The government has set out an ambituous strategy for economic adjustement and taken actions to lay the groundwork for debt relief. All these have severely affected Sudan's prospects for poverty reduction. It is estmated that $46 \%$ of its population live below the monetary poverty line and suffer deprivation in education, health and standard of living. In the 2014 Human Development Report Sudan is ranked in the 166 place out of 187 countries (World Bank, 2013a).

Since independence in 2011, the new nation - The Republic of South Sudan - faces the challenge of building its institutions and the fiscal environment has evolved under very difficult economic and political conditions. Even though the abundant oil revenues could have facilitated the country's economic and institutional development, in 2012 South Sudan experienced an oil shutdown followed by an armed conflict in 2013, and a significant drop in international oil prices. The response of the government to such difficult context has been to pursue a responsible fiscal plan. However, human development indicators in South Sudan point to extremely low living conditions as maternal mortality rates remain high with only $2 \%$ of live births, fully immunized children only account for $17 \%$, and around $80 \%$ of the population do not have access to toilet facilities and only 55\%s improved access to water resources (World Bank, 2013b).

Such insecurity and political instability has fragilized both countries' commitment to reducing poverty. Over the last decades, policy actions have faced a number of evaluation and implementation difficulties, including the challenge of quantifying poverty itself and assessing its correlates. A serious limitation for many years has been the lack of household budget surveys. The availability of the 2009 National Baseline Household Survey has fortunately changed that; it is Sudan's and South Sudan's first nationally representative household budget survey since 1978. This paper assesses multidimensional poverty in Sudan and South Sudan on the basis of that survey. In addition, it attempts to provide an appraisal of poverty by age-group to ensure that adults and also children are included explicitly in the Sustainable Development Goals (SDG's) agenda of these two countries. The SDG's under the umbrella of the 'leave no-one behind' puts social justice and equity at the heart of the wider agenda for eradicating extreme poverty. This requires that the development community through its various actors take action by ensuring to monitor the progress in human development of the most disadvantaged groups such as children or the elderly (UN, 2013).

The paper goes beyond a study focused solely on monetary poverty and considers nonincome-based dimensions. In so doing, this multidimensional analysis of poverty attempts 
to highlight those dimensions for which we may wish policy to have the greatest impact on the most needed segments of the population in Sudan and South Sudan. The data come from the National Baseline Household Surveys (NBHS) of 2009, which are nationally representative surveys containing information on education, health, labour, sources of household consumption, household characteristics and living conditions. We divide the population into two population sub-groups: children/teenagers aged 6 to 14 years and adults aged 15 years or older. To assess poverty status within each of these population groups, we assess their well-being separately using a four-dimension space. The dimensions selected for the analysis comprise education, food and non-food consumption, access to "public" assets and possession of "private" assets. These dimensions and their corresponding indicators have been selected for their intrinsic and instrumental importance, as is often the case in the development field (UNDP, 1990-2014).

This thus leads to an analysis of poverty in four dimensions for each of the two population sub-groups. We should note at the outset that although the assessment of poverty in both sub-groups covers the same dimensions, the indicators used for measuring education in each of them differ. For the adult group, education is measured by literacy, whereas for the 6-to-14 year-old group, education is measured by school attendance. Monetary poverty is measured by total per capita consumption, which includes food and non-food household consumption. Access to "public" assets is measured by indicators of the type of lighting, drinking water, solid waste disposal, and toilet facility used by a household. The information on public assets reflected by these 4 indicators is summarized in a composite score resulting from multiple correspondence analysis (MCA). Lastly, possession of "private assets" is measured by indicators denoting the ownership of $i$ ) durable goods (refrigerator, fan, air cooler), ii) vehicles (motor vehicle, motorcycle, bicycle), and iii) multimedia goods (television, radio, phone, computer). This information is also summarized in a composite score obtained from a multiple correspondence analysis.

The rest of the paper is structured as follows. In the next section we describe the patterns of welfare in each of the four dimensions by population sub-groups. To obtain a single measure of welfare in public and private assets respectively, Section 3 applies MCA to the corresponding indicators. Section 4 presents a unidimensional analysis of poverty; Section 5 presents the multidimensional analysis. The analysis of poverty in both sections, 4 and 5 , deals with poverty incidence (and breadth in section 5) and uses synthetic measures or poverty indices for this purpose. The multidimensional analysis of poverty applies the Alkire-Foster (2011) counting method. To test the robustness of the results to different poverty lines and alternative poverty indices across sociodemographic groups, poverty dominance analysis is performed in both sections. Section 6 discusses the policy implications of the study. Section 7 concludes the paper.

\section{Patterns of welfare by dimension}

This section describes the patterns of unidimensional welfare for each of the four dimensions considered in our analysis of multidimensional poverty. As mentioned above, the data used comes from the 2009 National Baseline Household Survey of Sudan. This 
survey has been conducted by the Sudan Commission for Census Statistics and Evaluation and the Central Bureau of Statistics of Sudan in 2009 prior to the division of the country. The 2009 NBHS of South Sudan covers 4297 households and 33660 individuals, whereas the NBHS of the same year for Sudan covers 8037 households and 48845 individualsBoth surveys contain information at national, regional, and state levels on education, health, labour, sources of household consumption (food and non-food expenses), household characteristics and living conditions, among other aspects.

\section{Education}

Our first dimension of multidimensional poverty is education. To assess well-being in this dimension, we look at the deprivation rates in the adult population and among children aged 6 to 14 years. Deprivation in education is a notion of poverty that is understood as the lack of educational achievements. In the adult group, a person is considered as deprived in education if he is illiterate. Given that children aged 6 to 14 years are of schooling age, we choose to measure deprivation in education by school attendance. Thus, a child/teenenger is considered to be deprived in education if he is not attending school ${ }^{3}$.

A comparison of the percentage of the illiterate adult population by gender across countries shows that illiteracy in South Sudan is higher than in Sudan. In the former, $72 \%$ of the adult population is illiterate compared to $38 \%$ in the latter. By gender, we see that in both countries female illiteracy rates are higher than those of males. This gender gap widens in South Sudan, where $44 \%$ of the the illiterate population are females compared to $24 \%$ in Sudan.

By age group, we find a contrasting pattern between South Sudan and Sudan. In South Sudan, most of the illiterate population is young (aged 15 to 29 years old) whereas in Sudan there is a higher concentration of illiterate adults among older groups. Thus, in South Sudan the 15-to-29 year-old group jointly accounts for $42 \%$ of the illiterate adults, and the 30 -to44 year-old group contributes with $30 \%$ of illiterate adults. The remaining $27 \%$ comes from older groups, aged 45 years or more. In Sudan, the contribution of young groups to illiteracy is lower. The 15-to-29 year-old group contributes with $31 \%$ of illiterate adults, while the 30 -to-44 year-old group contributes with $29 \%$ of illiterate adults. It is interesting to note that the contributions of groups aged 45 years or higher is large (40\%). Half of this contribution comes from the oldest adult group, i.e those aged 65 years or more. This finding suggests that any policy interested in increasing the litteracy of the adult population should target the young adults, especially in South Sudan (Table 1, panel A).

\section{Table 1: Deprivation in education}

\footnotetext{
${ }^{3}$ Apart from school attendance, the NBHS includes information on school enrollment (current or ever) as well. However, the presence of too many missing values in the school enrollment variables leads us to use school attendance as the indicator variable for measuring the educational achievement of children aged 6 to 14 years.
} 
Panel A: Illiteracy rates (adult population)

\begin{tabular}{ccr} 
& South Sudan & \multicolumn{1}{c}{ Sudan } \\
\hline National & $72 \%$ & $38 \%$ \\
Gender & & \\
Male & $28 \%$ & $13 \%$ \\
Females & $44 \%$ & $24 \%$
\end{tabular}

Contribution of age-groups to the national illiteracy rate

\begin{tabular}{crr}
\hline Age-group & & \\
$\mathbf{1 5 - 1 9}$ & $15 \%$ & $10 \%$ \\
$\mathbf{2 0 - 2 4}$ & $13 \%$ & $10 \%$ \\
$\mathbf{2 5 - 2 9}$ & $15 \%$ & $11 \%$ \\
$\mathbf{3 0 - 3 4}$ & $11 \%$ & $9 \%$ \\
$\mathbf{3 5 - 3 9}$ & $11 \%$ & $11 \%$ \\
$\mathbf{4 0 - 4 4}$ & $8 \%$ & $9 \%$ \\
$\mathbf{4 5 - 4 9}$ & $8 \%$ & $8 \%$ \\
$\mathbf{5 0 - 5 4}$ & $6 \%$ & $8 \%$ \\
$\mathbf{5 5 - 5 9}$ & $3 \%$ & $5 \%$ \\
$\mathbf{6 0 - 6 4}$ & $3 \%$ & $6 \%$ \\
$\mathbf{6 5}+$ & $6 \%$ & $14 \%$ \\
& $100 \%$ & $100 \%$ \\
\hline
\end{tabular}

Panel B: School unattendace rates (children aged 6-14 years old)

\begin{tabular}{|c|c|c|}
\hline & Sudan & Sudan \\
\hline National & $57 \%$ & $38 \%$ \\
\hline \multicolumn{3}{|c|}{ By gender } \\
\hline Male & $47 \%$ & $49 \%$ \\
\hline Females & $53 \%$ & $51 \%$ \\
\hline \multicolumn{3}{|c|}{ Age-group } \\
\hline 6-9 - national & $65 \%$ & $54 \%$ \\
\hline \multicolumn{3}{|c|}{ By gender } \\
\hline Male & $47 \%$ & $50 \%$ \\
\hline Females & $53 \%$ & $50 \%$ \\
\hline onal & $49 \%$ & $19 \%$ \\
\hline \multicolumn{3}{|c|}{ By gender } \\
\hline Male & $47 \%$ & $44 \%$ \\
\hline Females & $53 \%$ & $56 \%$ \\
\hline
\end{tabular}

By state, we observe that the illiteracy rates of the adult population in Sudan range from 25 to $55 \%$, compared to 54 to $83 \%$ in South Sudan. Western Darfur and Warap are the states with the highest illiteracy rates in Sudan and South Sudan, respectively. Looking at the literacy-illiteracy gaps by state, in Sudan, we find positive and negative gaps across the various states. Khartoum, Northern, River Nile, Al-Gezira, Northern Darfur, Whilte Nile, Red Sea, Southern Darfur and Sinnar show a positive gap, favouring literacy. We should note that the illiteracy rate in Khartoum is four times lower the literacy one, leading to a $60 \%$ gap. Al-Gadarif, Northern Kordofan, and Southern Kordofan are the states with the smallest literacy-illiteracy gaps, $2 \%, 1 \%$ and $1 \%$ respectively. Blue Nile, Kassala and Western Darfur exhibit a negative gap; in these three states, the adult illiteracy rates are above the literacy ones (Figure 1, panel A).

In contrast to Sudan, the literacy-illiteracy gaps across states in South Sudan are all negative. Upper Nile is the state with the smallest illiteracy-literacy gap (9\%) followed by Central Equatoria (10\%). The illiteracy rate in Western-Bahr-Al-Ghazal and Western Equatoria is twice the literacy one, leading to a $30 \%$ gap. The gap increases to $48 \%$ for Unity and 57\% for Northern-Bahr-Al-Ghazal. Eastern Equatoria, Lakes, Warap, and Jonglei exhibit a gap of around 65\%. (Figure 1, panel B)

Looking at gender gaps by state, Figure 2 (panels A and B) compares the percentage of illiterates among adult women and adult men, by state. Interestingly, in both countries, the states that perform better with regards to literacy rates among adults turn out to be those 
with the largest gender gaps (illiteracy rate of women minus that of men), disfavoring women.

Figure 1: Adult population: Literacy and illiteracy rates by State

\section{Panel A: Sudan}

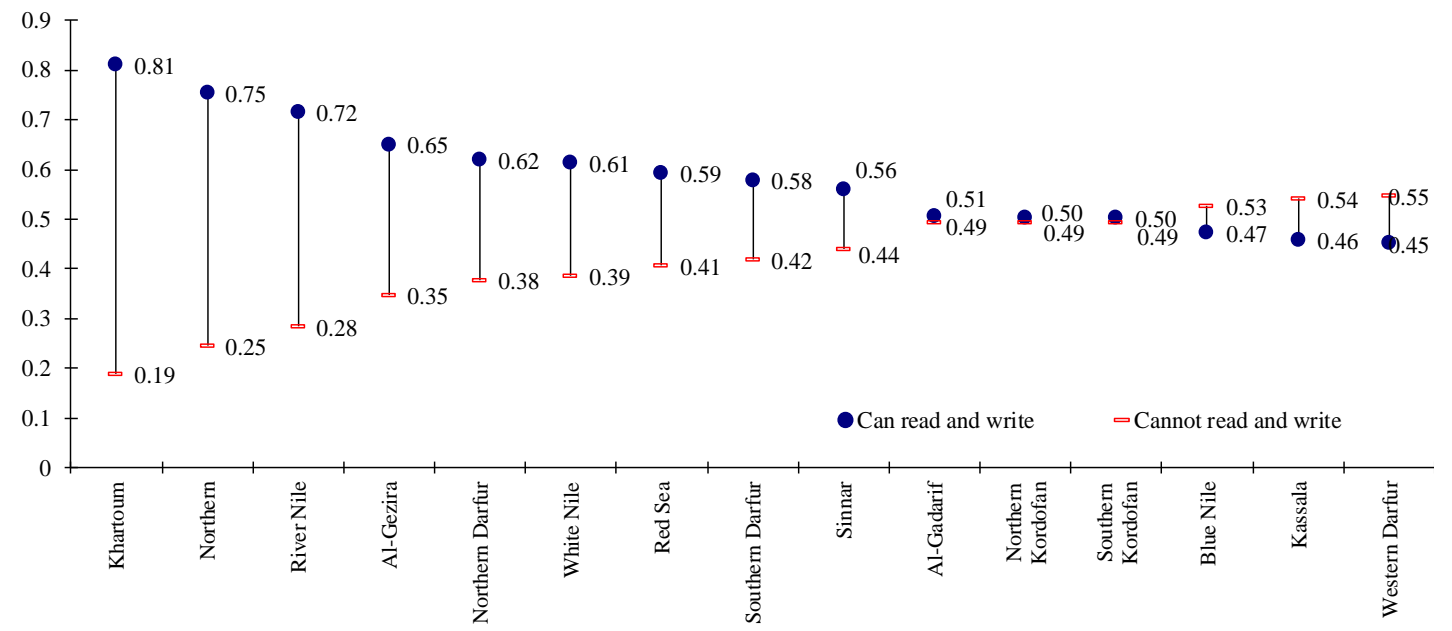

\section{Panel B: South Sudan}

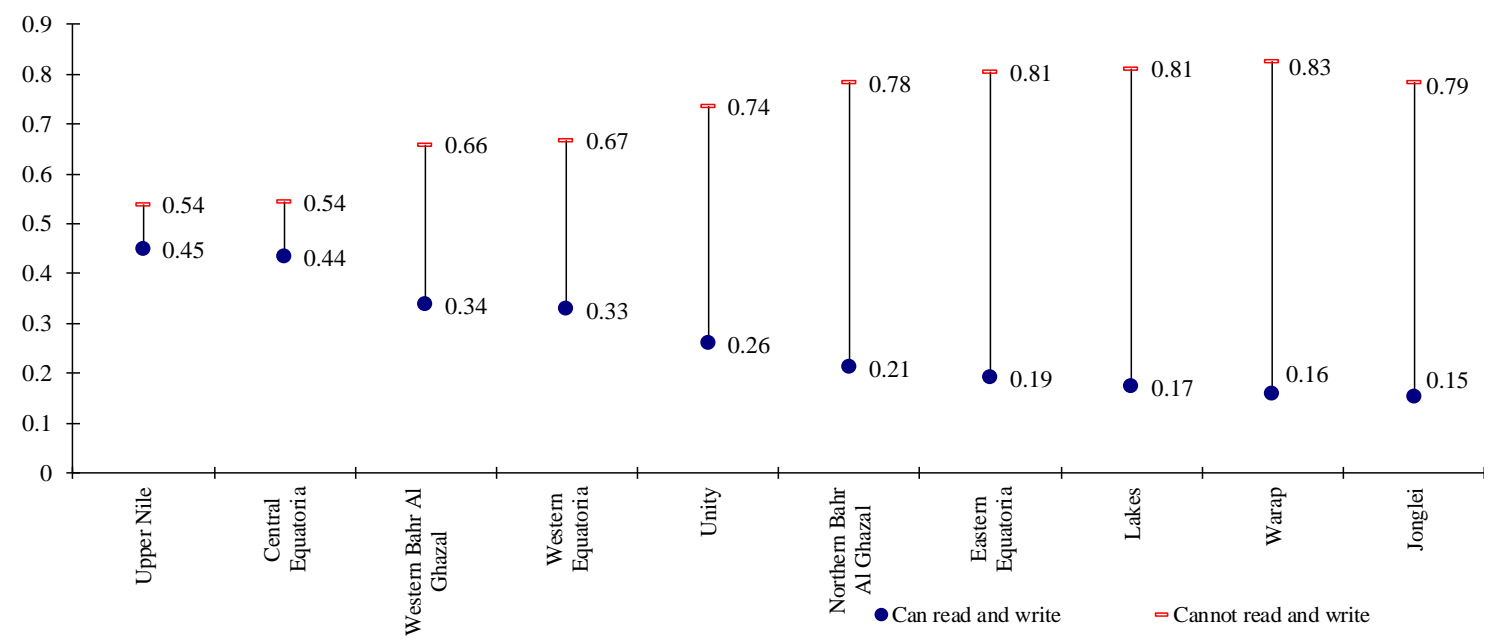


Figure 2: Gender status of the illiterate adult population, by State

\section{Panel A: Sudan}

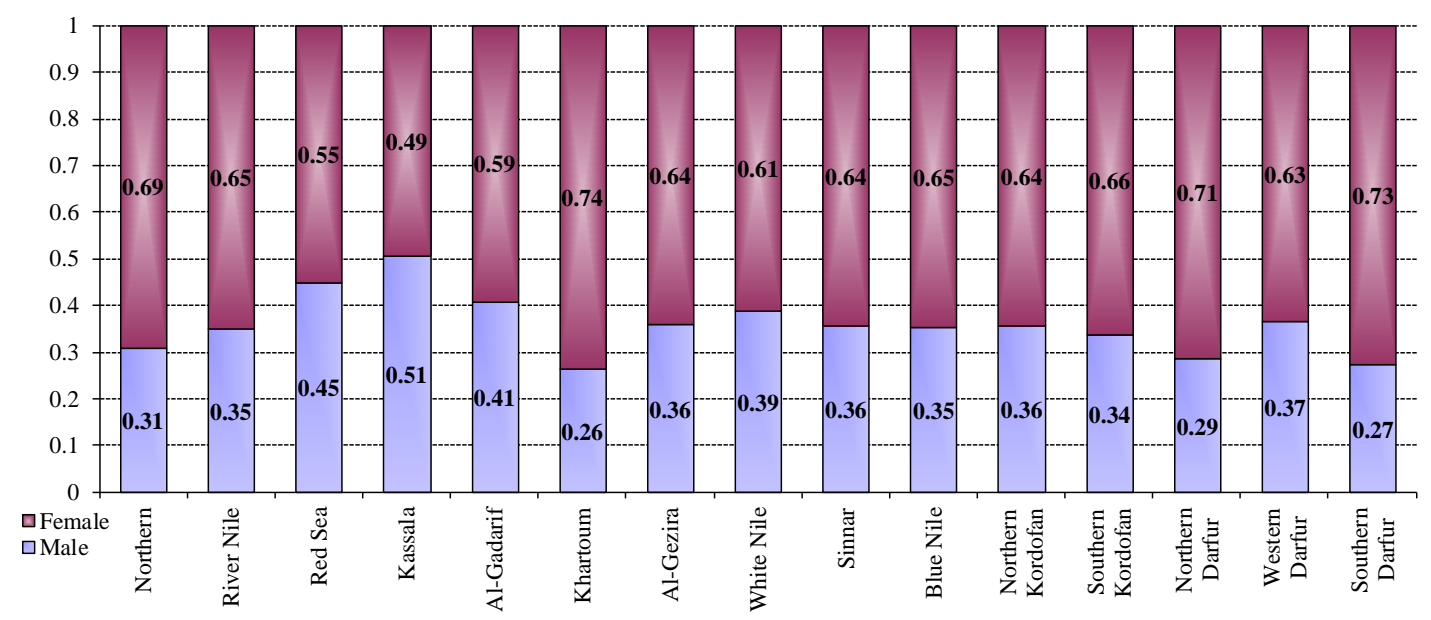

\section{Panel B: South Sudan}

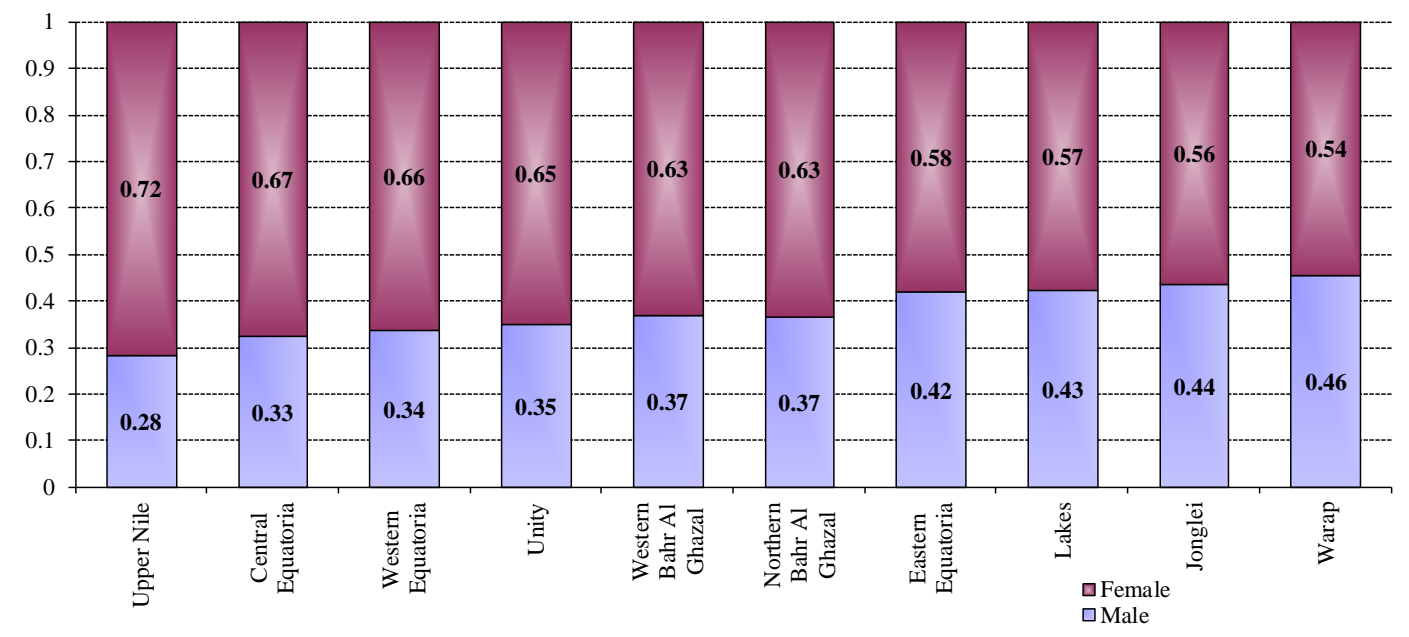

Thus, Khartoum and Upper Nile are the states in Sudan and South Sudan, respectively, with the largest gender gaps disfavoring women with regards to illiteracy (48\% and $44 \%$ respectively). The spatial distribution of illiteracy gender gaps across all other states for the two countries shows that most of these states exhibit gaps between 30 and $40 \%$, with some exceptions found in Eastern Equatoria (16\%), Lakes (14\%) Jonglei (12\%) and Warap 
(8\%) in South Sudan, and in Al-Gadarif (18\%), Read Sea (10\%) and Kassala (-2\%) in Sudan.

As with illiteracy, school unattendance rates of children aged 6 to 14 years old in South Sudan also exceed the Sudanese ones. In South Sudan, 57\% of children of this age group do not attend school; this percentage drops to $38 \%$ in Sudan, but it is still significant. We should note that these rates are considerably higher among younger children (65\% in South Sudan and 54\% in Sudan) compared to children aged 10 to 14 years old (49\% and 19\% respectively). From a policy perspective, this indicates that the severity of school unattendance lies within younger children, particularly in South Sudan. (Table 1, panel B).

To complete the analysis of school attendance, Figure 3 shows the percentage of boys and girls not attending school by age group and state. This is represented by four radars. We should note that the state percentages for a given age group add up to 100 .

In Sudan, girls' unattendance rates are higher among girls aged 10 to 14 years old compared to girls aged 6 to 9 years old in almost all states except for Western Darfur, Read Sea, and Sinnar. This is in contrast to the national pattern, where the severity of school unattendance lies within younger children (6 to 9 years old). This national pattern remains nonetheless true for the male population of children (Figure 3, panel A). In South Sudan, the same type of comparison does not show such marked state differences between girls and boys, except for Northern Bahr Al-Ghazal. The state-gender patterns are consistent with the national situation, where school unattendance rates are higher for the 6-to-9 year-old group of children compared to the 10-to-14 year-old group. In Northern Bahr Al-Ghazal, the 10-to14 year-old girls' unattendance rates surpass the 6 -to-9 year-old ones by $20 \%$.

Figure 3: Percentage of boys and girls among children aged 6 to 14 years not attending school, by State

\section{Panel A: Sudan}

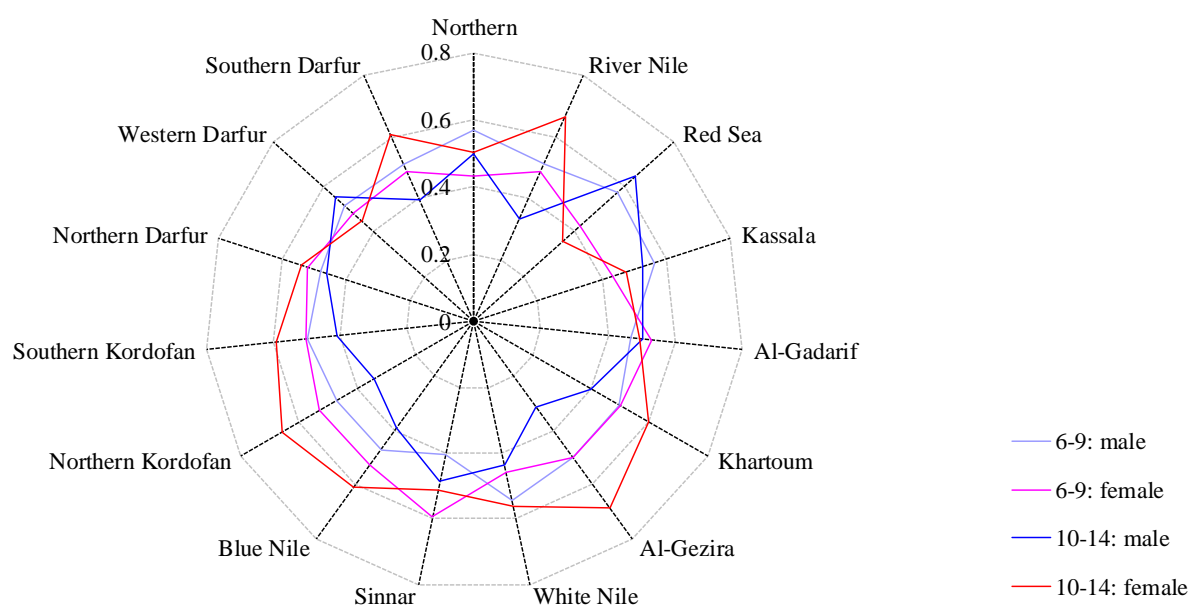




\section{Panel B: South Sudan}

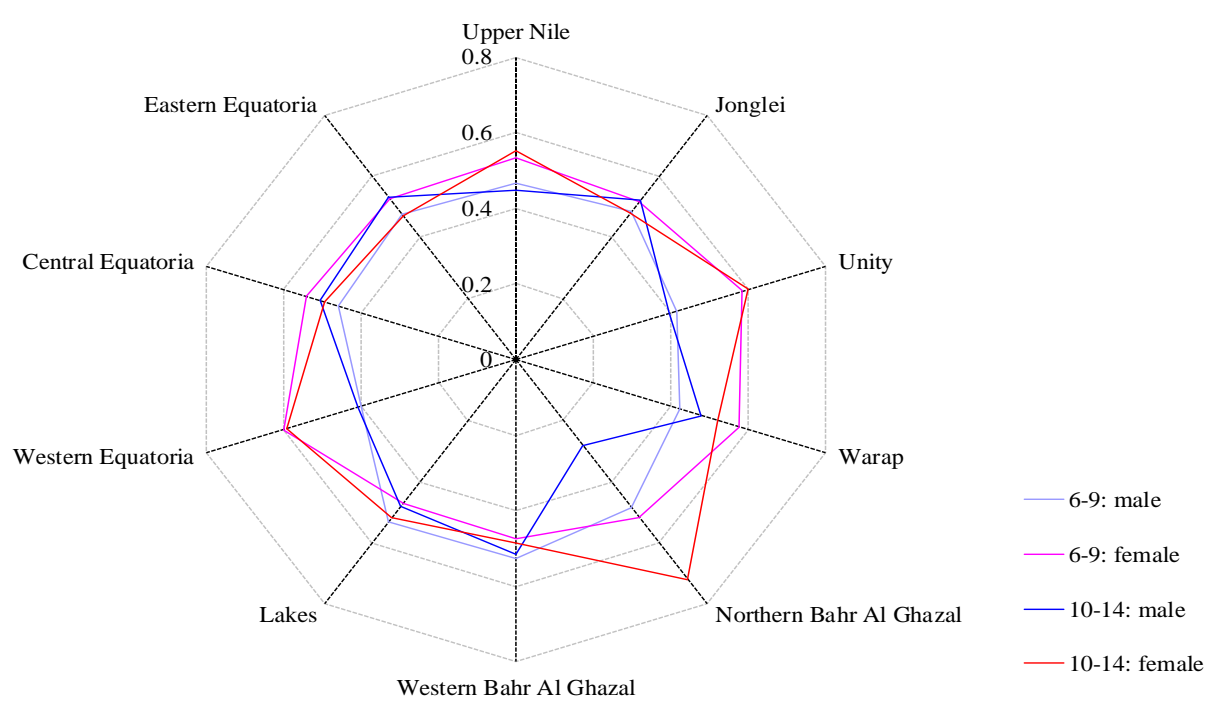

\section{Consumption}

Our second dimension of poverty appraisal in this multidimensional analysis is consumption. As the 2009 NHBS is Sudan's first nationally representative household budget survey since 1978, it is important to explain the steps followed for computing the consumption aggregate before describing the patterns of welfare in that dimension. The 2009 NHBS records household expenditures on food and non-food categories using a recall period for the last 7 days. The food sub-aggregate includes 14 categories of food consumed by the household from all possible sources: (i) food purchased from market, (ii) food that is home-produced, (iii) food received as gift or in-kind payment, and (iv) meals consumed outside the home. The non-food consumption household comprises expenses on education, utilities, personal care, health, house-related expenses, clothing, and transport, over the reference period (a year).

Following Deaton and Zaidi (2002) and Haughton and Khandker (2009), we first converted all reported expenditures on food items to a uniform reference period (a year) and then aggregated these expenditures across all food items purchased/consumed by the household. We then obtained the nominal consumption aggregate by adding up both categories of consumption, including the value of home-produced goods (but excluding the service value of durable goods). To account for cost-of-living differences, we deflated

the nominal consumption aggregate by a Laspeyres price index. ${ }^{4}$ Lastly, to reflect differences in needs of household members, we adjusted the (real) consumption aggregate

\footnotetext{
${ }^{4}$ It is sometimes argued that deflating nominal consumption aggregates by a Paasche price index is better, and that the use of a Laspeyres price index should be seen as a second best. The NBHS, however, includes a Laspeyres price index among the constructed variables, so for convenience we have opted for using this deflator.
} 
for household size by dividing the household's overall consumption by the number of its members.

A comparison of the consumption patterns by type of expense between South Sudan and Sudan suggests that households in Sudan are better off than those in South Sudan. The food share of households in South Sudan is 18\% higher than that of Sudan. However, the foodshare is quite large in both countries. In South Sudan, households allocate $79 \%$ of their total budget to food expenses; this share decreases to $61 \%$ in Sudan but remains considerable. Although the non-food share differs across countries, with Sudan exhibiting a higher non-food share, when looking at the composition of non-food expenses, we observe a similar pattern of non-food consumption in these two countries. Households in South Sudan and Sudan spend 73\% of their non-food resources in health, transport, utilities, and house-related expenses. Despite this similarity, a difference is evident by item of expense, especially in transport and house-related expenses. Households in Sudan spend $4 \%$ more in transport and $5 \%$ less in house-related expenses compared to their counterparts in South Sudan. With regards to education expenses, households spend on average in both countries no more than around $6 \%$ of their non-food resources on education. This may be explained by the fact that education in these countries is mostly public (Table 2).

Table 2: Household expenses by sub-category of consumption

\begin{tabular}{|c|c|c|c|}
\hline $\begin{array}{l}\text { Shares in total } \\
\text { consumption }\end{array}$ & South Sudan & Sudan & $\begin{array}{c}\text { Absolute Gap } \\
\text { SS-Sudan }\end{array}$ \\
\hline Food share & $79 \%$ & $61 \%$ & $18 \%$ \\
\hline Non-food share & $21 \%$ & $39 \%$ & $-18 \%$ \\
\hline \multicolumn{4}{|c|}{ Expenses by category of non-food item } \\
\hline Education & $5 \%$ & $6 \%$ & $-2 \%$ \\
\hline Health & $19 \%$ & $17 \%$ & $1 \%$ \\
\hline Clothing & $11 \%$ & $9 \%$ & $3 \%$ \\
\hline Utilities & $18 \%$ & $19 \%$ & $-1 \%$ \\
\hline Transport & $18 \%$ & $23 \%$ & $-4 \%$ \\
\hline Personal care & $8 \%$ & $9 \%$ & $-1 \%$ \\
\hline Recreation & $2 \%$ & $2 \%$ & $0 \%$ \\
\hline House-related expenses & $18 \%$ & $14 \%$ & $5 \%$ \\
\hline Other & $2 \%$ & $2 \%$ & $0 \%$ \\
\hline Total & $100 \%$ & $100 \%$ & \\
\hline
\end{tabular}

\section{Public and private assets}

The third and fourth dimensiosn we consider for assessing multidimensional welfare deprivation in South Sudan and Sudan are $i$ ) household access (and quality of this access) to "public" assets, and ii) their possession of "private" assets. The term "public" is used to denote assets that are shared by more than one household. These are mainly those basic services such as electricity and energy, water and sanitation, and waste removal, services that are critical to improve the lives of people. The term "private" is used to denote assets that are part of the daily life of a household. These two types of assets attempt to capture aspects of material deprivation that are different from consumption expenditures. 
The NBHS includes indicators of the source of lighting, source of drinking water, type of solid waste disposal and type of toilet facility used by a household. We use these four indicators to assess welfare in access to public assets. To study welfare in private assets, we use indicators denoting the ownership of $i$ ) durable goods (refrigerator, fan, air cooler), ii) vehicles (motor vehicle, motorcycle, bicycle), and iii) multimedia goods (television, radio, phone, computer) by a household.

The welfare pattern in the distribution of public assets indicates that households in Sudan are better off in their access to and quality of public assets compared to households in South Sudan. Sudanese households use better forms (better quality) of lighting and drinking water as well as a finer type of toilet facility and solid waste disposal than South Sudanese households. In Sudan, the main source of drinking water of households is filtered water (20\% of households) whereas in South Sudan only $2 \%$ of households use this source of drinking water, with the main source of drinking water being boreholes (35\% of households). With regards to lighting, a similar conclusion emerges. Sudanese households use gas/private or public electricity as the main source of lighting (44\% of households). This type of lighting is used by only 3\% of households in South Sudan, where the most used source is firewood/candle wax/solar power (42\% of households). As per toilet facility and solid disposal, Table 3 shows that $80 \%$ of households in South Sudan have no toilet facility and that $71 \%$ of them burn their solid disposals. In Sudan, households use latrines and bins as their main type of toilet facility and method of solid disposal, respectively. By area, a similar picture emerges, although to a lower extent for urban households (Table 3, panel A).

The welfare pattern in the distribution of private assets also points favorabily towards Sudanese houeholds. These households own more of all types of durable goods (especially fan and refrigerator), more of all sorts of multidimedia goods and more motor vehicles. It is interesting to note that in South Sudan's household ownership is particulary weak in durable goods - despite owning more bicycles, since these are vehicles of lesser value. Overall in South Sudan, the welfare status of households in this dimension is mostly characterized by the possession of relatively accessible and inexpensive goods such as a bicycle, radio or telephone (around 27\%). In contrast, more than 95\% of households do not own any durable good (refrigerator, fan, or air cooler). This high percentage of deprivation is also true for the possession of a motor vehicle, motorcycle, television or computer. (Table 3, panel B).

\section{Multiple correspondence analysis}

As our study of welfare in assets includes many indicators, we opt for a simple measure to profile asset welfare across these dimensions. Among the multivariate statistical methods that aim for data reduction descriptively (i.e., non model-based), principal component analysis (PCA) and multiple correspondence analysis (MCA) are prominent. ${ }^{5}$ MCA is

\footnotetext{
${ }^{5}$ Other uses of this method comprise the analysis of multidimensional poverty, where all dimensions of
} 
similar to PCA and both methods attempt to summarize the information contained in a large number of variables by reducing and transforming the original data into a lesser number of variables, referred to as components (for PCA) or axes (for MCA). In both cases, the reduction in dimensionality is achieved withouth specifying a statistical model as it is the case with factor analysis and related techniques, referred as model-based methods. In addition to data reduction, these methods are also used for modeling abstract concepts.

As our aim is to reduce and not model poverty/deprivation, we opt for descriptive methods of the kind of PCA/MCA. MCA (which we use) can be thought of as an analogue to principal component analysis but applied to categorical data. The aim of multiple correspondence analysis is to account for a maximum amount of inertia along the first axis. Given this axis, the second axis accounts for a maximum of the remaining inertia, and so on. Hence, total inertia can be split into dimensions along principal axes (Greenacre and Blasius, 2006).

\section{Table 3: Distribution of household asset indicators}

\section{Panel A: Public assets (main source in \%)}

\begin{tabular}{|c|c|c|}
\hline "Public" asset & $\begin{array}{l}\text { South } \\
\text { Sudan }\end{array}$ & Sudan \\
\hline \multicolumn{3}{|l|}{ Source of drinking water } \\
\hline Water filtering & 2 & 20 \\
\hline Boreholes & 35 & 41 \\
\hline Hand pump & 34 & 10 \\
\hline Running open water & 24 & 9 \\
\hline \multirow[t]{2}{*}{ Water vendor } & 4 & 20 \\
\hline & 100 & 100 \\
\hline \multicolumn{3}{|l|}{ Source of lighting } \\
\hline Gas, private or public electricity & 3 & 44 \\
\hline Paraffin, grass, biogas & 28 & 28 \\
\hline Firewood, candle wax, solar power & 42 & 13 \\
\hline \multirow[t]{2}{*}{ No lighting } & 27 & 15 \\
\hline & 100 & 100 \\
\hline \multicolumn{3}{|l|}{ Main type of toilet facitily } \\
\hline Latrine & 19 & 61 \\
\hline Private, shared or bucket toilet & 1 & 8 \\
\hline \multirow[t]{2}{*}{ No toilet facility } & 80 & 32 \\
\hline & 100 & 100 \\
\hline \multicolumn{3}{|l|}{ Main method for solid disposal } \\
\hline Bin & 5 & 25 \\
\hline Heap or pit & 24 & 29 \\
\hline \multirow[t]{2}{*}{ Burning or other } & 71 & 46 \\
\hline & 100 & 100 \\
\hline
\end{tabular}

\section{Panel B: Private assets} (ownership in\%)

\begin{tabular}{|c|c|c|c|}
\hline \multicolumn{2}{|c|}{ "Private" asset } & \multirow{2}{*}{$\begin{array}{r}\text { South } \\
\text { Sudan }\end{array}$} & \multirow{2}{*}{$\begin{array}{r}\text { Sudan } \\
8.4\end{array}$} \\
\hline Vehicles & Motor vehicle & & \\
\hline & Motor cycle/moto & 4.2 & 2.8 \\
\hline & Bicycle & 26.7 & 11.1 \\
\hline \multirow{3}{*}{$\begin{array}{l}\text { Mutlimedia } \\
\text { goods }\end{array}$} & Television & 4.5 & 38.3 \\
\hline & Radio/transistor & 27.7 & 49.5 \\
\hline & Phone & 18.5 & 55.7 \\
\hline \multirow{4}{*}{$\begin{array}{l}\text { Durable } \\
\text { goods }\end{array}$} & Computer & 0.9 & 4.6 \\
\hline & Refrigerator & 1.3 & 22.1 \\
\hline & Fan & 1.6 & 27.2 \\
\hline & Air cooler & 0.8 & 7.1 \\
\hline
\end{tabular}

interest are reduced to only one (c.f. Asselin, 2009). 
To achieve this, MCA analyses a multiway table of all associations amongst pairs of indicators (variables), including each association between an indicator and itself. This multiway table of cross-tabulations is referred as the Burt matrix. Such a representation helps understand the similarities between the categories of each indicator and the association between pairs of indicators. For the purposes of reduction in dimensionality, the results of the MCA offer a geometric representation of these similarities or dissimilarities. Based on this resemblance, we are able to interpret and condense the indicator categories into a lesser number of composites, which is our aim for public and private assets. Operatively, MCA performs a simple corrrespondece analaysis on the Burt matrix. The main advantage of MCA is its optimal scaling property. The coordinates of the categories on the principal axis provide an optimal scale, since the observation (or respondent) scores obtained form these scale values have the largest variance among all possible scale values that are subject to the same identification conditions. This means that if one is interested in the quantification of the scale values of each indicator which leads to the greatest discrimination between respondents, then MCA provides that solution.

\section{MCA of “public” assets}

The results of multiple correspondence analysis performed on indicators of public assets suggests a two-axis representation of the 15 categories (4 indicators) characterizing public assets in both countries ${ }^{6}$. In Sudan, the first two orthogonal axes account for $93.2 \%$ of total inertia (Figure 1 Panel A) while in South Sudan the two leading axes account for $79.4 \%$ of the total inertia (Figure 1 Panel B) ${ }^{7}$. The bi-plots make it easier to see data associations and similarity of categories. In a biplot, column categories mapped close together have similar column profiles, whereas categories mapped widely apart have dissimilar column profiles. A clear pattern is seen in these bi-plots. In Sudan, the first axis (horizontal) clearly differentiates low and medium from high types of public assets, whereas in South Sudan the first axis differentiates low from medium and high types of public assets. This corroborates our preceding descriptive analysis of public assets in which households in Sudan were found to be better off in their access to and quality of public assets compared to households in South Sudan.

In terms of the coordinates, in Sudan low types (no toilet facility, no lighting or firewood, hand pump, and burning of solid disposals) and medium types (running open water or water vendor, paraffin, and heap) are grouped together to the left and placed with negative coordinates, whereas high types of public assets (gas, water filtering, private/shared toilet, and bin) are placed to the right with positive coordinates (Figure 4, Panel A). In South Sudan, the coordinate map shows a different placement: low types are clustered together to the left with negative coordinates, and high and medium types are clustered to the right, with positive coordinates (Figure 4, Panel B). The vertical axis provides additional insights

\footnotetext{
${ }^{6}$ Please refer to Appendix A.1 for details regarding the quality of fit and \% of inertia of the MCA solution. Note that MCA was performed separately for each country.

${ }^{7}$ As a heuristic rule, in MCA a minimum number of axes is usually retained to explain at least $70 \%$ of the inertia. This is analogous to similar heuristic rules on the number of components in PCA. As the axes in MCA are orthogonal, we may add the contributions of the axes.
} 
to the grouping, mainly among low and medium types in Sudan and among medium and high types in South Sudan.

Figure 4: MCA biplot - indicators of public assets

\section{Panel A: Sudan}



Note: Coordinates in principal normalization

\section{Panel B: South Sudan}

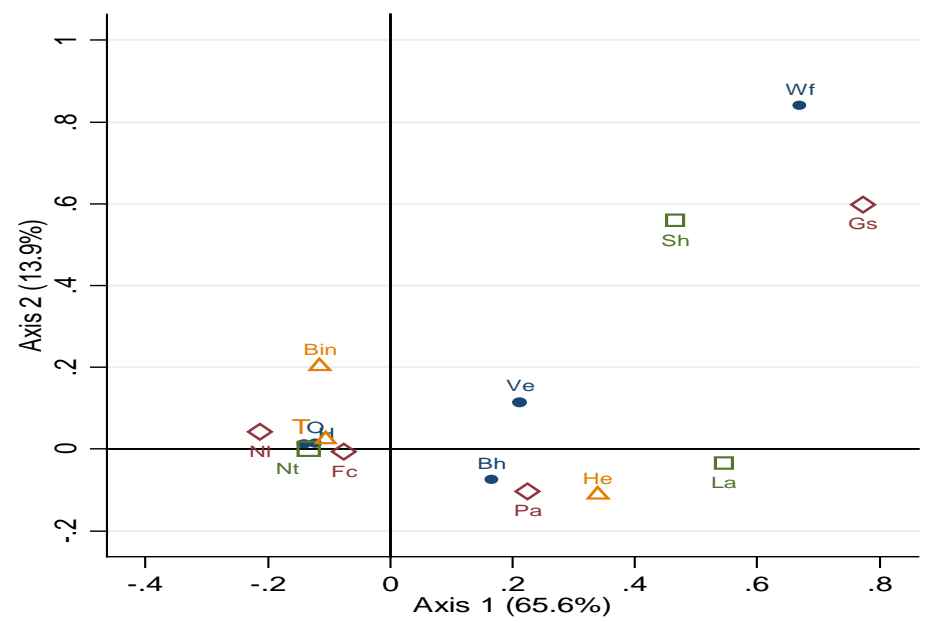

- Source of drinking water

$\diamond$ Source of energy lighting

$\square$ Toilet facility

$\Delta$ Source of waste disposal

Note: Coordinates in principal normalization 
To complete our analysis, we obtain the optimal scaling positions for the households in our survey. This is the prediction of the scores of each household on each of the two axes obtained from MCA. We only compute the scores for the first axis since our main objective is to use a single measure of public assets to analyse poverty in a multidimensional setting. This measure summarizes the information provided by the four public assets indicators and is the one we use in the next two sections.

\section{MCA of "private" assets}

As with public assets, we also apply MCA to the indicators of private assets in each country. The results of the solutions also suggest a two-axis representation of the 18 categories (9 indicators) used to measure private assets in both countries ${ }^{8}$. The decomposition of total inertia in two orthogonal axes shows that the first two axes account for $90 \%$ of total intertia in each country (Figure 5, Panels A and B).

\section{Figure 5: MCA biplot - indicators of private assets}

\section{Panel A: Sudan}

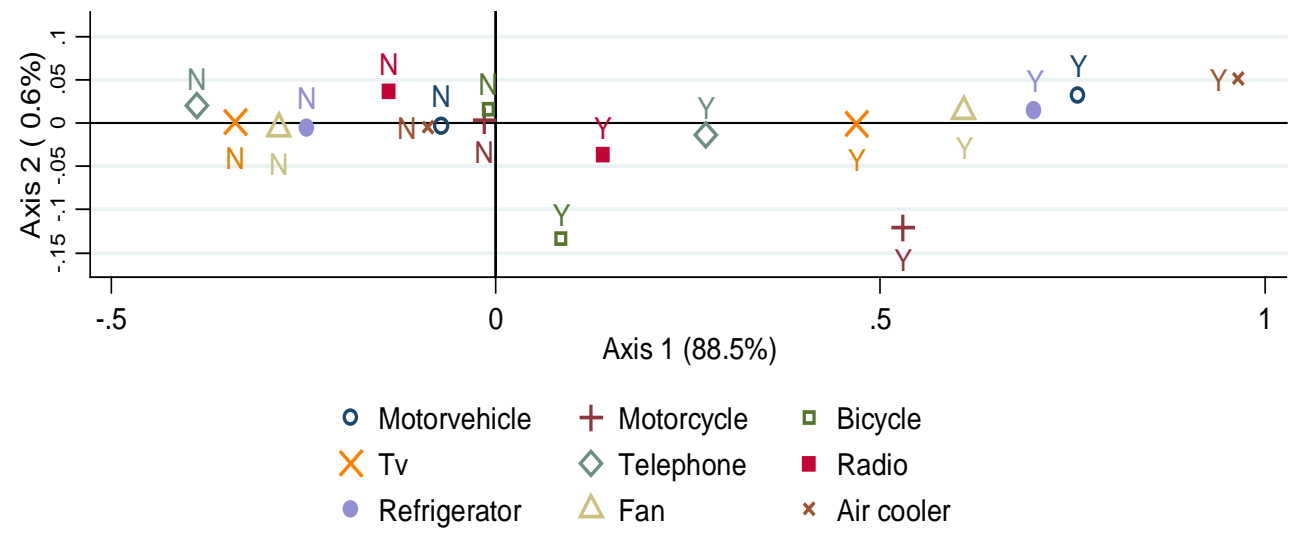

Note: Coordinates in principal normalization

\footnotetext{
${ }^{8}$ Please refer to Appendix A.2 for details regarding the quality of fit and \% of inertia of the MCA solution. Note that MCA was performed separately for each country.
} 


\section{Panel B: South Sudan}



The bi-plots in each country do not differ much. Each clearly differentiates ownership from lack of ownership. In the first horizontal axis, all categories denoting possession of a private asset have a positive coordinate, whereas those denoting the lack of ownership have a negative coordinate and are mapped close together, indicating very similar column profiles. The vertical axis in both bi-plots does not provide additional insights to this categorisation as it contributes very little to total inertia.

As for public assets, we obtain the optimal scaling positions for the households in our survey using the solutions of the MCA applied to each country. As before, we only compute the scores for the first axis since our goal is to use a single measure of private assets to analyse poverty in a multidimensional setting.

\section{Unidimensional poverty}

Section 3 described the patterns of welfare status among Sudanese and South Sudanese households. In this section, we assess more directly the extent of their poverty. The analysis compares population subgroup poverty among (i) adults aged 15 years and older and (ii) children aged 6 to 14 years for each country. For a given population subgroup, 
unidimensional poverty is understood as the lack of sufficient welfare in that domain.

\section{Poverty among adults (15 years old and older)}

The appraisal of adult poverty considers four domains of welfare deprivation - education, consumption, private and public assets. As is standard in poverty studies, a two-step procedure is used. The first step sets a criterion for identifying the poor in each dimension. The second step aggregates the status of all poor individuals using a poverty measure, in our case the headcount ratio. ${ }^{9}$ Our criteria for poverty identification in the adult group for both countries is the following: a person is identified as deprived in education if she is illiterate and is monetary poor if his real per capita consumption is below the national poverty line; The national poverty line we use for consumption is the official poverty line in each country. In Sudan this is equal to 114.8 SDGs, and in South Sudan this is equal to 72.94 SDGs $^{10}$. With these poverty lines, $41 \%$ of the Sudanese population and $49 \%$ of the South Sudanese population, respectively, are idenfied as consumption poor. To be consistent with these headcount ratios, we therefore fix the poverty lines in both types of assets at the $40^{\text {th }}$ and $50^{\text {th }}$ percentiles of the distribution of the scores in Sudan and South Sudan respectively, which, accounting for bunching at the given percentile, results in a slightly higher rate (by around 1\% above). Hence, a person is deprived in public or private assets if his score is below a given percentile of the distribution of scores, the $40^{\text {th }}$ percentile in Sudan and the $50^{\text {th }}$ percentile or the median in South Sudan.

A comparison of the dimensional poverty incidence rates by country shows a constrasting dimensional profile. In South Sudan, education is the dimension with the highest poverty rate (74\%); this is followed by private and public assets, where poverty incidence is around $54 \%$, and monetary poverty, where $49 \%$ of South Sudanese adults are identified as consumption poor. In Sudan, dimensional poverty figures are are less dispersed. Around $41 \%$ of sudanese households are idenfified as poor in either consumption, private assets or public assets. The lowest incidence rate is found in education, where $38 \%$ of the adult population is illiterate. It is interesting to note the constrasting difference in the incidence of poverty in education between these two countries. Education is the dimension with the lowest incidence among the adult population in Sudan but is also the one with the highest incidence among the same agegroup in South Sudan.

When compared across countries, the dimensional profiles indicate that all dimensions of poverty are higher in South Sudan, with the greatest gap being in education. By area, we observe that rural poverty is the area that contributes the most to poverty across all four dimensions in both countries. This is reflected by the higher poverty rates of the rural areas compared to the urban ones in each country. We should note that the rural incidence rates in consumption, private assets and public assets across countries are very similar. To test for the robustness of these results to different poverty lines, we have applied stochastic

\footnotetext{
${ }^{9}$ Due to the presence of non-cardinal education indicators (literacy and school attendance) and to the lack of adequate cardinality of the scores obtained from MCA, we limit our analysis to poverty incidence, that is, to FGT-zero - see Foster et al, 1984.

${ }^{10}$ See also, the Sudan Central Bureau of Statistics and the Southern Sudan Centre for Census, Statistics and Evaluation for details regarding its calculation.
} 
dominance tests (Davidson and Duclos, 2000). Although we do not report the detailed results here, they show that for all possible poverty lines and for all poverty indices that are monotonically decreasing in welfare, poverty in urban areas is always lower than in rural areas in each of the two countries of our study (Table 4, columns 3 and 4) ${ }^{11}$.

By Sudanese states, Khartoum exhibits the lowest poverty incidence in three out of the four dimensions: education, consumption and private assets, while the lowest poverty incidence in public assets is found in Northern. The greatest poverty incidence is found in Southern Kordofan for public assets, Northern Darfur for consumption and private assets, and in Western Darfur for education (Table 5, panel A). In contrast to Sudan, South Sudan's capital state (Central Equatoria) exhibits the lowest poverty rate in education only; the other three poverty rates are nevertheless below the national average. Western Equatoria, Western B. Al-Ghazal and Upper Nile are the states exhibiting the lowest incidence in public assets, private assets and consumption, respectively. In South Sudan, the greatest poverty incidence, by dimension, is found across three states: Warap (education), Northern B. Al-Ghazal (consumption), and Jonglei (public and private assets) (Table 5, panel $\mathrm{A}^{12}$ ).

Table 4: Unidimensional poverty incidence (Headcount ratios in \%)

\begin{tabular}{|c|c|c|c|c|c|}
\hline \multirow[b]{2}{*}{ Dimension } & \multirow[b]{2}{*}{ Area } & \multicolumn{2}{|c|}{ Adults aged 15+ } & \multicolumn{2}{|c|}{ Children aged 6 - 14 years } \\
\hline & & Sudan & South Sudan & Sudan & South Sudan \\
\hline \multirow[t]{3}{*}{$\begin{array}{l}\text { Education } \\
\end{array}$} & Urban & 21.0 & $\overline{47.6}$ & 14.4 & 31.4 \\
\hline & Rural & 49.9 & 79.1 & 38.2 & 58.7 \\
\hline & National & 38.3 & 73.8 & 30.2 & 54.7 \\
\hline \multirow[t]{3}{*}{ Consumption } & Urban & 22.8 & 22.6 & 33.3 & 25.9 \\
\hline & Rural & 53.1 & 54.5 & 65.9 & 56.2 \\
\hline & National & 41.0 & 49.1 & 54.9 & 51.8 \\
\hline \multirow[t]{3}{*}{ Private assets } & Urban & 14.0 & 17.9 & 19.7 & 21.1 \\
\hline & Rural & 60.6 & 62.4 & 67.7 & 63.5 \\
\hline & National & 41.9 & 54.9 & 51.4 & 57.4 \\
\hline \multirow[t]{3}{*}{ Public assets } & Urban & 12.0 & 27.4 & 17.4 & 30.4 \\
\hline & Rural & 59.9 & 58.8 & 74.3 & 59.5 \\
\hline & National & 40.7 & 53.5 & 55.1 & 55.3 \\
\hline
\end{tabular}

\footnotetext{
${ }^{11}$ Standard errors and confidence intervals of each estimated poverty rate are reported in Appendix A.3, Table A.3.1.

${ }^{12}$ Standard errors and confidence intervals of each estimated poverty rate are reported in Appendix A.3, Table A.3.2.
} 


\section{Poverty among children aged 6 to 14 years}

The measurement of unidimensional poverty among children also considers four dimensions - education, consumption, private and public assets. As for the adult group, we follow two-step criteria for measuring poverty among children. We identify a child as deprived in education if he is not attending school. Similarly, a child is considered as monetary poor if his real per capita consumption is below the national per capita poverty line of 114.8 SDGs in Sudan, and 72.94 SDGs in South Sudan, respectively. With these poverty lines, 55\% of the Sudanese children aged 6 to 14, and 52\% of the South Sudanese children of the same age are respectively idenfied as consumption poor. To be consistent with these headcount ratios, we therefore fix the poverty lines in both types of assets at the $55^{\text {th }}$ and $52^{\text {nd }}$ percentiles of the distribution of the scores in Sudan and South Sudan respectively.

By dimension, we observe that in South Sudan the dimension with the highest incidence of poverty among children is in private assets, whereas in Sudan children suffer more in terms of consumption poverty than the adult group. Interestingly, as in the adult group, education remains the dimension with the lowest incidence of poverty among children in Sudan. The lowest incidence among children in South Sudan is found in consumption.

In contrast to the poverty profiles of the adult population, the children's dimensional poverty profiles between Sudan and South Sudan do not show marked differences. While poverty incidence in consumption is higher in Sudan than in South Sudan, poverty in education and in private assets is lower and poverty in public assets is almost the same in both countries (Table 4, columns 5 and 6).

As per the adult group, we observe that the rural area is where poverty is the greatest across all four dimensions in both countries. In addition, when looking at the area contribution to national poverty, we see that in Sudan more than $80 \%$ of national poverty is concentrated in rural areas, for all dimensions. This percentage increases to $90 \%$ in South Sudan (see Appendix A.4) ${ }^{13}$. As with the adult group, we have also applied stochastic dominance tests to test for the robustness of these results to different poverty lines and indices (Davidson and Duclos, 2000). We do not report the detailed results here but they show that for all possible poverty lines and for all poverty indices that are monotonically decreasing in welfare, poverty in urban areas is always lower than in rural areas in each of the two countries of our study.

Across Sudanese states, Khartoum exhibits the lowest poverty rates among all four dimensions. Kassala, Northern Darfur, Western Darfur and Northern Kordofan exhibit the highest poverty rates in education, consumption, private assets, and public assets, respectively (Table 5, panel B). In South Sudan, Western Equatoria, exhibits the lowest poverty rate in education, private and public assets, and Upper Nile exhibits the lowest poverty incidence in consumption. Interestingly, the greatest dimensional-poverty

\footnotetext{
${ }^{13}$ Standard errors and confidence intervals of each estimated poverty rate are reported in Appendix A.3, table A.3.3.
} 
incidence in South Sudan among children is found in the same three states as those of the adult population: Warap (education), Northern B. Al-Ghazal (consumption), and Jonglei (public and private assets) (Table 5, panel B).

Table 5: Unidimensional poverty incidence, by State

\begin{tabular}{|c|c|c|c|c|c|c|c|c|}
\hline \multirow[b]{4}{*}{ State } & \multicolumn{4}{|l|}{ Panel A } & \multicolumn{4}{|l|}{ Panel B } \\
\hline & \multirow{2}{*}{\multicolumn{4}{|c|}{$\begin{array}{l}\text { Adults aged 15+ } \\
\text { Head Count ratio (\%) }\end{array}$}} & \multicolumn{4}{|c|}{ Children aged $6-14$ years old } \\
\hline & & & & & \multicolumn{4}{|c|}{ Head Count ratio (\%) } \\
\hline & Education & Consumption & $\begin{array}{l}\text { Private } \\
\text { assets }\end{array}$ & $\begin{array}{l}\text { Public } \\
\text { assets }\end{array}$ & Education & Consumption & $\begin{array}{r}\text { Private } \\
\text { assets }\end{array}$ & $\begin{array}{l}\text { Public } \\
\text { assets }\end{array}$ \\
\hline Sudan & 38.3 & 41.0 & 41.9 & $\overline{40.7}$ & 30.2 & 54.9 & 51.4 & 55.1 \\
\hline Northern & 25.3 & 32.5 & 18.8 & 8.2 & 16.4 & 45.1 & 24.1 & 14.1 \\
\hline River Nile & 28.9 & 29.9 & 30.7 & 16.2 & 15.1 & 39.2 & 41.2 & 28.8 \\
\hline Red Sea & 41.7 & 44.0 & 46.1 & 26.5 & 23.3 & 59.4 & 55.8 & 32.6 \\
\hline Kassala & 54.7 & 32.8 & 58.9 & 58.5 & 48.8 & 41.7 & 67.4 & 68.3 \\
\hline Al-Gadarif & 50.5 & 44.2 & 48.0 & 52.3 & 38.3 & 60.0 & 52.6 & 62.5 \\
\hline Khartoum & 19.3 & 22.3 & 11.2 & 8.7 & 13.2 & 33.4 & 17.0 & 15.7 \\
\hline Al-Gezira & 35.7 & 33.3 & 28.4 & 31.8 & 25.0 & 46.6 & 32.5 & 38.8 \\
\hline White Nile & 39.4 & 52.6 & 50.3 & 49.2 & 29.5 & 60.0 & 52.2 & 55.0 \\
\hline Sinnar & 45.0 & 41.1 & 48.1 & 47.1 & 36.7 & 50.7 & 54.8 & 52.6 \\
\hline Blue Nile & 53.9 & 52.3 & 52.3 & 52.3 & 30.7 & 63.5 & 59.9 & 57.2 \\
\hline Northern Kordofan & 50.7 & 52.4 & 63.7 & 70.5 & 39.4 & 69.1 & 68.5 & 86.0 \\
\hline Southern Kordofan & 50.6 & 57.7 & 55.3 & 77.8 & 38.1 & 65.8 & 62.4 & 84.3 \\
\hline Northern Darfur & 38.7 & 69.1 & 74.7 & 49.2 & 25.9 & 77.4 & 74.2 & 58.3 \\
\hline Western Darfur & 55.3 & 48.9 & 71.5 & 76.9 & 42.4 & 62.5 & 78.4 & 82.5 \\
\hline Southern Darfur & 43.1 & 53.4 & 58.3 & 54.4 & 36.1 & 65.4 & 68.0 & 76.7 \\
\hline South Sudan & 73.8 & 49.1 & 54.9 & 53.5 & 54.7 & 51.8 & 57.4 & 55.3 \\
\hline Upper Nile & 56.0 & 26.0 & 51.7 & 58.6 & 38.7 & 25.3 & 51.7 & 58.0 \\
\hline Jonglei & 84.4 & 46.4 & 78.3 & 78.4 & 55.0 & 48.6 & 79.7 & 81.1 \\
\hline Unity & 75.3 & 66.6 & 55.2 & 55.7 & 58.6 & 69.2 & 55.4 & 56.7 \\
\hline Warap & 84.6 & 63.8 & 67.7 & 78.2 & 74.1 & 63.4 & 73.8 & 78.3 \\
\hline North.B.Al Ghazal & 80.4 & 74.5 & 53.5 & 61.8 & 62.9 & 77.4 & 55.1 & 61.5 \\
\hline West.B.Al Ghazal & 66.8 & 39.6 & 28.8 & 49.5 & 57.9 & 47.8 & 33.8 & 54.7 \\
\hline Lakes & 83.2 & 49.2 & 46.7 & 47.8 & 65.0 & 48.3 & 43.0 & 48.7 \\
\hline Western Equatoria & 67.9 & 39.6 & 29.8 & 10.0 & 30.4 & 47.0 & 24.8 & 8.9 \\
\hline Central Equatoria & 55.9 & 40.3 & 32.7 & 15.2 & 36.7 & 48.0 & 39.3 & 17.8 \\
\hline Eastern Equatoria & 81.3 & 47.2 & 74.7 & 59.1 & 68.9 & 54.6 & 78.8 & 64.7 \\
\hline
\end{tabular}

\section{Multidimensional poverty}

This section assesses poverty in Sudan and South Sudan under a multidimensional aggregation framework. Our aim is to provide insights into the joint deprivations of South Sudanese and Sudanese households in a simple manner. For this purpose, we apply the methodology proposed by Alkire and Foster (2011), referred to as AF.

The AF method identifies the poor using two cutoffs: one within a dimension and one across dimensions. To aggregate total poverty, it employs the FGT measures appropriately 
adjusted to account for multidimensionality. The dimensional cutoff is a traditional dimension-specific deprivation cutoff, which identifies a person as deprived if he falls below a (dimensional) poverty line. The cross-dimensional cutoff, denoted by $k$, states how widely deprived a person must be in order to be considered multidimensionally poor; to determine if someone should be considered multidimensionally poor, $k$ is compared to the count of the dimensions in which the person is deprived. When $k$ equals one, the AF identification method is analogous to the union approach, and when $k$ equals the total number of dimensions, the AF identification method is identical to the intersection approach - see for instance Duclos, et. al (2006) for a discussion. Hence, with the union approach, a person is identified as poor if she is deprived in at least one dimension; with the intersection approach, a person is identified as poor if she is deprived in all dimensions. Clearly, the appraisal of poverty is sensitive to the value of $k$. We deal with this sensitivity by considering all possible values of $k$, in our case from 1 to 4 (or, in relative terms, from 25 to $100 \%)$.

Although the AF method proposes a family of measures that can reflect the incidence, depth and severity of multidimensional poverty, the analysis here focuses on multidimensional poverty incidence. In this case, the AF measure gives an adjusted headcount ratio $M_{0} \in[0,1]$ that is the product of two indices, namely,

$$
M_{0}=H^{*} A,
$$

where $H$ is the multidimensional headcount ratio - or the percentage of people identified as poor using the dual cutoff approach - and $A$ is the average proportion of deprivations in which the poor are deprived. Hence, the adjusted headcount ratio $M_{0}$ is an index that combines information on the prevalence of poverty $(H)$ and on the average extent of the poor's deprivation ( $A$ ) breadth. As with the FGT unidimensional measures, $M_{0}$ can be decomposed by population subgroups and can also be broken down by indicator/dimension (although with some cost in coherency, see Duclos, 2011). This allows to assess the dimensional deprivations that contribute the most to poverty for any given subgroup as well as to identify which group contributes most to national poverty. We should note that although $M_{0}$ does not capture inequality among the poor one could further the analysis by including a squared count measure that accounts for inequality (Alkire and Foster, 2016). However this goes beyond the scope of the paper.

\section{Multidimensional poverty among adults aged 15 years or more}

Table 5, panel A, presents the adjusted headcount ratio $\left(M_{0}\right)$, the multidimensional headcount ratio $(H)$, and the average extent of the poor's deprivation $(A)$ among the adult population in Sudan and South Sudan, for a cross dimensional cutoff of $50 \%$ ( $k=$ $2)^{14}$. The dimensional cut-offs are those employed above for poverty identification in the

${ }^{14}$ In Appendix A.4, table A.4.1, we also report the values of these indices for $k>=1, k>=3$ and $k=4$. In the 
unidimensional case. The cross-dimensional cutoff of 50\% states that an adult, in either of the two countries, is identified as multidimensionally poor if he is deprived in at least $50 \%$ of dimensions, or equivalently in at least 2 out of the 4 dimensions considered in this study. Following the international global multidimensional poverty index (MPI) reported in the Human Development Report since 2010 (UNDP, 2010) we asign the same normative importance (or the same weight) to each indicator/dimension when computing the adjusted headcount ratio ${ }^{15}$.

A comparision of the multidimensional poverty profiles of the adult population in Sudan and South Sudan indicates that multidimensional poverty measured by the adjusted headcount ratio, $\left(M_{0}\right)$, is higher in South Sudan $\left(M_{0}=0.5\right)$ than in Sudan $\left(M_{0}=0.4\right)$. In terms of poverty prevalence and breadth, we observe that poverty incidence in the former is almost $25 \%$ higher than in the latter; that is, $49 \%$ of the adult population in Sudan is multidimensionnally poor. This rate increases to $73 \%$ in South Sudan. In other words, around half of the adult population in Sudan and three quarters in South Sudan are deprived in at least 2 (out of 4) dimensions. Interestingly, although in South Sudan the prevalence of multidimensional poverty is higher than in Sudan, the intensity or breadth of poverty in both countries is very similar. In Sudan, the multidimensionally poor adults are deprived in $73 \%$ of all dimensions, and in South Sudan this percentage increases to $74 \%$ of dimensions. This is, in both countries the adult population that is multidimensionnally poor suffers deprivations in 3 out of 4 dimensions on average.

\section{Table 5: Multidimensional poverty indices $\mathrm{K}>=\mathbf{2}$}

Panel A

\begin{tabular}{|c|c|c|c|c|c|c|c|c|c|c|c|c|}
\hline \multirow{4}{*}{ Area } & \multicolumn{6}{|c|}{ Adults aged 15+ } & \multicolumn{6}{|c|}{ Children aged 6 - 14 years } \\
\hline & \multicolumn{3}{|c|}{ Sudan } & \multicolumn{3}{|c|}{ South Sudan } & \multicolumn{3}{|c|}{ Sudan } & \multicolumn{3}{|c|}{ South Sudan } \\
\hline & $\mathbf{H}$ & $\mathbf{A}$ & M0 & $\mathbf{H}$ & $\mathbf{A}$ & M0 & $\mathbf{H}$ & $\mathbf{A}$ & Mo & $\mathbf{H}$ & $\mathbf{A}$ & M0 \\
\hline & $(\%)$ & $(\%)$ & Index & $(\%)$ & $(\%)$ & Index & $(\%)$ & $(\%)$ & Index & $(\%)$ & $(\%)$ & Index \\
\hline Urban & 18.0 & 62 & 0.11 & 34.3 & 76 & 0.26 & 23.3 & 62 & 0.14 & 30.7 & 65 & 0.20 \\
\hline Rural & 69.6 & 74 & 0.52 & 80.1 & 74 & 0.60 & 77.5 & 75 & 0.58 & 76.6 & 73 & 0.56 \\
\hline National & 48.9 & 72 & 0.35 & 72.7 & 74 & 0.54 & 59.2 & 74 & 0.44 & 69.9 & 72 & 0.50 \\
\hline
\end{tabular}

However, the dimensional contribution to overall poverty is not the same across countries. A closer look at the relative contribution of each dimension to overall poverty (Table 6, panel A) provides some insights on those dimensions that affect the poor the most. In South Sudanese education is the dimension that contributes the most (29\%) to national Sudanese multidimensional poverty of the adult population; this is followed by private and public assets (24\% both), and consumption (22\%). Once again, as with the undimensional profile,

same appendix, we also report the standard errors and confidence intervals of each estimated poverty index when $\mathrm{k}>=2$. Note that the conclusions reported for $\mathrm{k}>=2$ in this section are robust to the choice of $\mathrm{k}$ value.

${ }^{15}$ For a discussion about normative choices and redundancy analysis among deprivation indicators of a multidimensional counting poverty measure please refer to Alkire et. al (2015), chapters 6 and 7. 
we see that in South Sudan a third of overall poverty comes from deprivation in education, this is from adults who are both illiterate and multidimensional poor. With regards to Sudan, the dimensional contributions indicate that private and public assets are the dimensions where there is the greatest concentration of multidimensional poverty (28 and $26 \%$, respectively). The remaining $46 \%$ of total multidimensional poverty comes from education and consumption (23\% each).

When looking at the sub-group poverty profiles by area of residence, we see that prevalence and breadth of multidimensional poverty are higher among adults residing in the rural areas of each country. However, the regional gaps of both poverty prevalence and breadth are not similar across countries. While the rural-urban gap of poverty incidence is $52 \%$ in Sudan and is $56 \%$ in South Sudan, this same gap is quite different when looking at the breadth of poverty. Noticably, in South Sudan multidimensionnally poor adults residing in either area (urban or rural) suffer the same extent of deprivation (74\% or 3 dimensions out of 4). On the contrary, in Sudan there seems to be an important difference in the breadth of poverty across adults residing in urban and rural areas. Those who live in urban regions and are multidimensionnally poor are deprived (on average) in 2 dimensions, while those who live in rural areas are deprived in 3 . These two aspects of poverty, namely breadth and prevalence, are reflected in the values of the adjusted headcount ratios by area of residence. The $M_{0}$ values show that while in rural Sudan the index is 0.5, in urban Sudan it falls to 0.1 . This regional difference is not as large in South Sudan where rural $M_{0}$ is half of urban $M_{0}$. To test the robustness of these results, we have also applied bi-stochastic dominance analysis (Duclos et al., 2006), which showed that poverty in rural areas is always higher than in urban areas regardless of the choice of multidimensional poverty indices and multidimensional poverty lines.

\begin{tabular}{|c|c|c|c|c|}
\hline \multirow[b]{2}{*}{ Dimension } & \multicolumn{4}{|c|}{$K>=2$} \\
\hline & $\begin{array}{c}\text { Sudan } \\
15+\end{array}$ & $\begin{array}{c}\text { SS } \\
15+\end{array}$ & $\begin{array}{c}\text { Sudan } \\
6-14\end{array}$ & $\begin{array}{c}\text { SS } \\
6-14\end{array}$ \\
\hline Total per capita expenditure & 23.2 & 22.3 & 26.4 & 23.0 \\
\hline Education & 22.7 & 29.0 & 16.0 & 25.2 \\
\hline Private Assets & 27.6 & 24.3 & 28.2 & 26.9 \\
\hline Public Assets & 26.5 & 24.4 & 29.4 & 24.9 \\
\hline
\end{tabular}

By state, we see that in Sudan, Khartoum is the state where multidimensional poverty is the weakest ( $M_{0}$ equal to 0.09 ), both in terms of prevalence and breadth. In Khartoum 14\% of adults are identified as multidimensionally poor and experience on average deprivation in $62 \%$ of dimensions (around 2 out of 4 ). The largest index of multidimensional poverty is found in Western Darfur (0.59). When accounting for the population size of the state, we observe that the greatest contribution to national poverty in Sudan comes from Northern Kordofan (12\%), where poverty prevalence and breadth are around 75\% and where the $M_{0}$ value of 0.56 is well above the national average of 0.35 (Table 7, panel A). 
In South Sudan, the state profiles show that Western Equatoria is the state with the lowest multidimensional poverty index (0.27) and with the lowest intensity of poverty $(57 \%$ of dimensions). The weakest incidence is found in Central Equatoria, the capital state. The highest $M_{0}$ value is found in Jonglei (0.74), which is mostly due to the notably high poverty incidence rate of 95\%. In Warap, poverty breadth is the largest. In this state multidimensionally poor adults experience an average deprivation share of $80 \%$ of dimensions, equivalent to about 3 out of 4 dimensions. Warap is also the state that contributes the most to overall multidimensional poverty; Warap contributes $24 \%$ of national poverty among adults (Table 7, panel A).

\section{Multidimensional poverty among children aged 6 to 14 years}

Table 5, panel B, displays the adjusted headcount ratios and its two sub-indices $(H, A)$ for a cross-dimensional cutoff of 50\% $(k=2)^{16}$ among children aged 6 to 14 years in Sudan and South Sudan. As with the adult group, when calculating the multidimensional poverty indices for children we apply the same dimensional cut-offs used for poverty identification in the unidimensional case.

The multidimensional poverty profiles of children across these two countries do not show much variation with regards to the adult case. Poverty, as measured by the adjusted headcount ratio, is still higher in South Sudan than in Sudan by 0.06 points. The prevalence of poverty among children in Sudan is $10 \%$ lower than in South Sudan, but the breadth of poverty is slightly higher (in $2 \%$ ). By area, we still observe that children living in rural areas suffer more than in urban areas in terms of intensity and incidence of poverty in each country, note however that $M_{0}$ and its two subindices, $H$ and $A$ are very similar between the two countries. With regards to the regional gaps, the breadth regional gap in South Sudan is larger among children than among adults, but it it does not vary across population groups in Sudan. In terms of intensity, we see that the regional gap (rural-urban) widens in Sudan and shrinks in South Sudan compared to the adult population. To test the robustness of these results, we have again applied bi-stochastic dominance analysis, which showed that poverty in rural areas is always higher than in urban areas regardless of the choice of multidimensional poverty indices and multidimensional poverty lines.

In contrast to adult poverty, the dimensional contribution of each dimension to overall poverty indicates a shift in the dimension that contributes most to overall poverty among children in South Sudan, but not so among children in Sudan. In South Sudan, private assets is the dimension that contributes the most to overall poverty among children (27\%), in constrast to education which was the leading contributing dimension to national poverty among adults in South Sudan. In Sudan however, private and public assets remain the two dimensions that contribute the most to national poverty among children (Table 6), as for adults.

\footnotetext{
${ }^{16}$ In Appendix A.4, table A.4.2, we also report the values of these indices for $\mathrm{k}>=1, \mathrm{k}>=3$ and $\mathrm{k}=4$. In the same appendix we also report the standard errors and confidence intervals of each estimated poverty subindex when $\mathrm{k}>=2$.
} 
Children-state profiles in Sudan resemble in part those of the adult group. Khartoum is also the state where multidimensional poverty is the weakest, in terms of prevalence and breadth of multidimensional poverty. In contrast to the adult group, the highest index and greatest incidence among children are found in two states, Western Darfur and Northern Kordofan, while the greatest intensity is found in Kassala (79\%). In Khartoum 22\% of children are multidimensionally poor and, on average, experience deprivation in $61 \%$ of dimensions, whereas in Western Darfur and Northern Kordofan these rates shift to 81\% and 78\%, respectively. Accounting for the population size of the state, the greatest contribution to children national poverty in Sudan comes from Northern Kordofan (13\%) (Table 7, panel B).

In South Sudan, the state profiles of poverty among children clearly point towards two states: Western Equatoria and Warap. In contrast to the adult group, Western Equatoria is the state with not only the lowest multidimensional poverty index (0.19) and the lowest intensity of poverty ( $56 \%$ of dimensions), but also the one with the lowest incidence (33\%). Conversely, Warap is the state where the largest $M_{0}$ value (0.70) and the greatest poverty incidence (89\%) and breadth (79\%) are found. In this state, $89 \%$ of children are multidimensionally poor, with an average deprivation share of $79 \%$ of dimensions. Warap is also the state that contributes the most to overall multidimensional poverty among children. (Table 7, panel A).

Table 7: Multidimensional poverty indices, by state

Panel A

\begin{tabular}{|c|c|c|c|c|}
\hline \multirow{3}{*}{ State } & \multicolumn{4}{|c|}{ Adults aged 15 $+(k=>2)$} \\
\hline & \multirow{2}{*}{$\begin{array}{c}\mathbf{H} \\
(\%)\end{array}$} & \multirow{2}{*}{$\begin{array}{c}A \\
(\%)\end{array}$} & \multicolumn{2}{|c|}{ MO } \\
\hline & & & Index & Cont. \\
\hline Sudan & 48.9 & 72 & 0.35 & 100.0 \\
\hline Northern & 20.3 & 62 & 0.13 & 1.0 \\
\hline River Nile & 28.5 & 67 & 0.19 & 2.4 \\
\hline Red Sea & 48.2 & 70 & 0.34 & 2.0 \\
\hline Kassala & 61.5 & 78 & 0.48 & 7.7 \\
\hline Al-Gadarif & 61.8 & 72 & 0.44 & 5.8 \\
\hline Khartoum & 14.5 & 62 & 0.09 & 5.4 \\
\hline Al-Gezira & 38.7 & 69 & 0.27 & 9.6 \\
\hline White Nile & 59.6 & 72 & 0.43 & 7.5 \\
\hline Sinnar & 55.9 & 72 & 0.40 & 5.1 \\
\hline Blue Nile & 64.2 & 74 & 0.47 & 3.7 \\
\hline Northern Kordofan & 74.6 & 75 & 0.56 & 12.9 \\
\hline Southern Kordofan & 75.4 & 75 & 0.57 & 7.9 \\
\hline Northern Darfur & 77.2 & 70 & 0.54 & 7.5 \\
\hline Western Darfur & 76.0 & 78 & 0.59 & 5.9 \\
\hline Southern Darfur & 65.0 & 74 & 0.48 & 15.7 \\
\hline South Sudan & 72.7 & 74 & 0.53 & 100.0 \\
\hline Upper Nile & 57.1 & 67 & 0.38 & 7.7 \\
\hline Jonglei & 95.4 & 77 & 0.74 & 16.4 \\
\hline Unity & 75.4 & 73 & 0.55 & 6.9 \\
\hline Warap & 94.5 & 80 & 0.75 & 24.6 \\
\hline North.B.Al Ghazal & 82.4 & 77 & 0.63 & 10.8 \\
\hline West.B. Al Ghazal & 63.9 & 70 & 0.45 & 2.3 \\
\hline Lakes & 72.8 & 70 & 0.51 & 7.6 \\
\hline Western Equatoria & 47.7 & 57 & 0.27 & 4.4 \\
\hline Central Equatoria & 45.2 & 66 & 0.30 & 8.8 \\
\hline Eastern Equatoria & 82.9 & 77 & 0.64 & 10.5 \\
\hline
\end{tabular}

Panel B

Children aged $6-14$ years old $(k=>2)$

\begin{tabular}{|c|c|c|c|}
\hline \multirow{2}{*}{$\begin{array}{c}\mathbf{H} \\
(\%)\end{array}$} & \multirow{2}{*}{$\begin{array}{c}\text { A } \\
(\%)\end{array}$} & \multicolumn{2}{|c|}{ MO } \\
\hline & & Index & Cont. \\
\hline 59.2 & 74 & 0.44 & 100.0 \\
\hline 25.1 & 65 & 0.16 & 0.7 \\
\hline 39.8 & 65 & 0.26 & 1.9 \\
\hline 55.6 & 68 & 0.38 & 1.5 \\
\hline 69.0 & 79 & 0.54 & 7.3 \\
\hline 66.4 & 73 & 0.49 & 6.0 \\
\hline 21.9 & 61 & 0.13 & 5.0 \\
\hline 43.9 & 68 & 0.30 & 7.9 \\
\hline 61.9 & 72 & 0.44 & 6.5 \\
\hline 58.6 & 74 & 0.44 & 4.2 \\
\hline 67.2 & 72 & 0.48 & 3.4 \\
\hline 81.8 & 77 & 0.63 & 13.2 \\
\hline 79.4 & 75 & 0.60 & 8.1 \\
\hline 80.3 & 70 & 0.56 & 7.5 \\
\hline 81.4 & 78 & 0.63 & 6.5 \\
\hline 75.0 & 78 & 0.58 & 20.1 \\
\hline 69.9 & 72 & 0.50 & 100.0 \\
\hline 56.3 & 67 & 0.38 & 10.0 \\
\hline 88.5 & 72 & 0.64 & 17.8 \\
\hline 76.5 & 73 & 0.56 & 6.9 \\
\hline 89.2 & 79 & 0.70 & 17.9 \\
\hline 83.6 & 73 & 0.61 & 11.4 \\
\hline 61.4 & 69 & 0.43 & 3.1 \\
\hline 70.1 & 66 & 0.46 & 7.6 \\
\hline 33.6 & 56 & 0.19 & 2.7 \\
\hline 42.6 & 68 & 0.29 & 7.4 \\
\hline 81.9 & 78 & 0.64 & 15.3 \\
\hline
\end{tabular}




\section{VI . Policy recommendations}

\section{Unidimensional poverty}

Our analysis of the patterns and the distribution of unidimensional welfare (summarized in Table 8) across Sudan and South Sudan shows that illiteracy rates are higher and concentrated among the younger population in South Sudan, in contrast to Sudan, where illiteracy is more present among older age groups. A gender gap disfavouring women is also found to be larger among South Sudanese adults than Sudanese ones. As with illiteracy, the South Sudanese school unattendance rates of children aged 6 to 14 years exceed the Sudanese ones. These rates are considerably higher among young children compared to children aged 10 to 14 years old in each country. From a policy angle, this indicates that the severity of school unattendance is greater for younger children, and particularly so in South Sudan.

The patterns of consumption by type of expense indicate that households in Sudan are better off than those in South Sudan. In both countries, the food share is nevertheless quite large and the composition of non-food expenses shows a similar pattern, with households in both countries spending three quarters of their resources on health, transport, utilities, and house-related expenses.

The distribution of public assets also suggests that households in Sudan are better off in their access to and quality of public assets compared to households in South Sudan. Sudanese households use better forms (better quality) of lighting, drinking water as well as finer types of toilet facility and solid waste disposal than South Sudanese households. The distribution of private assets also points favorably towards Sudanese households. These households own more of all types of durable goods (especially fan and refrigerator), more of all sorts of multidimedia goods, and more motor vehicles. It is interesting to note that ownership of households in South Sudan is particulary weak in durable goods.

The unidimensional analysis of poverty among adults indicates that poverty is higher in South Sudan than in Sudan in all dimensions, with the greatest gap between the two countries being in education poverty. By dimension, our analysis of poverty shows a constrasting dimensional profile across our two countries of study. Sudan's dimensional profile shows greatest incidence in private assets and lowest incidence in education, whereas South Sudan's greatest incidence is found in education and the lowest incidence in consumption. Rural poverty contributes most to total poverty across all four dimensions and in both countries. The cross-country comparison of rural poverty shows similar poverty rates in consumption, private assets and public assets. South Sudan has greater rural incidence in education compared to Sudan. In Sudan, Western Darfur, Southern Kordofan and Northern Darfur are the states with the greatest incidence of poverty in education, public assets, consumption and private assets, respectively; the lowest incidence across education, consumption and private assets is found in Khartoum. The states' poverty profiles in South Sudan point towards Warap, Northern B.Al.Gazal, and Jonglei as the states with the highest poverty rates in education, consumption, public and private assets, respectively; the lowest poverty rates are found in Central Equatoria, Upper Nile, Western 
Equatoria and Western B.Al.Gazal in those same four dimensions (Table 8, panel A).

\section{Table 8: Unidimensional poverty profiles}

\begin{tabular}{|c|c|c|c|c|c|c|c|}
\hline \multicolumn{4}{|l|}{ Panel A } & \multicolumn{4}{|l|}{ Panel B } \\
\hline \multicolumn{4}{|c|}{ Adults aged 15+ $(k>=2)$} & \multicolumn{4}{|c|}{ Children aged 6 to years old $(k>=2)$} \\
\hline & Sudan & & South Sudan & & Sudan & & South Sudan \\
\hline \multicolumn{4}{|c|}{ By dimension } & \multicolumn{4}{|c|}{ By dimension } \\
\hline$\overline{\text { Greatest incidence }(\mathrm{H})}$ & Private assets & & Education & Greatest incidence $(\mathrm{H})$ & Consumption & & Private assets \\
\hline Lowest incidence $(\mathrm{H})$ & Education & & Consumption & Lowest incidence $(\mathrm{H})$ & Education & & Consumption \\
\hline \multicolumn{4}{|c|}{ By dimension and area of residence } & \multicolumn{4}{|c|}{ By area of residence } \\
\hline Greatest incidence $(\mathrm{H})$ & & & & Greatest incidence $(\mathrm{H})$ & & & \\
\hline Education & & $<$ & & Education & & $<$ & \\
\hline Consumption & & $\approx$ & & Consumption & Rural & $>$ & Rural \\
\hline Public assets & Rural & $\approx$ & Rural & Public assets & Rural & $<$ & Rural \\
\hline Private assets & & $\approx$ & & Private assets & & $>$ & \\
\hline \multicolumn{4}{|c|}{ By dimension and state } & \multicolumn{4}{|c|}{ By state } \\
\hline Greatest incidence $(\mathrm{H})$ & & & & Greatest incidence (H) & & & \\
\hline Education & Western Darfur & $<$ & Warap & Education & Kassala & $<$ & Warap \\
\hline Consumption & Northern Darfur & $<$ & North.B.Al Gazal & Consumption & Northern Darfur & $\approx$ & North.B.Al Gazal \\
\hline Public assets & Southern Kordofan & $1<$ & Jonglei & Public assets & Western Darfur & $\approx$ & Jonglei \\
\hline Private assets & Northern Darfur & $\approx$ & Jonglei & Private assets & Northern Kordofan & $>$ & Jonglei \\
\hline Lowest incidence $(\mathrm{H})$ & & & & Lowest incidence $(\mathrm{H})$ & & & \\
\hline Education & Khartoum & $<$ & Central Equatoria & Education & Khartoum & $<$ & Western Equatoria \\
\hline Consumption & Khartoum & $<$ & Upper Nile & Consumption & Khartoum & $>$ & Upper Nile \\
\hline Public assets & Northern & & Western Equatoira & Public assets & Khartoum & & Western Equatoria \\
\hline Private assets & Khartoum & $<$ & West.B.Al Gazal & Private assets & Khartoum & $>$ & Western Equatoria \\
\hline
\end{tabular}

Children's dimensional poverty profiles also contrast across countries. Within country, these profiles differ from the adults' profiles, especially with regards to the dimension with the greastest incidence. We find that consumption and private assets are the dimensions with the greatest incidence among children, in Sudan and South Sudan respectively. Interestingly, the lowest poverty rates by dimension, among children, are found in the same dimensions as those of the adult population, namely, education and consumption, in Sudan and South Sudan respectively. By area, as with the adult population, rural poverty contributes the most to poverty across all four dimensions and in both countries. However, in contrast to the adult group, the rural poverty rates are not all lower in Sudan compared to South Sudan; rural poverty in consumption and private assets is higher in Sudan compared to South Sudan. By state, much as with the adult group, Khartoum has the lowest poverty incidence (in all dimensions) in Sudan, whereas the highest poverty rates in education, consumption, public and private assets are found in Kassala, Northern Darfur, Western Darfur and Northern Kordofan. The states' child poverty profiles in South Sudan show the greastest dimensional incidence in the same four states as for the adult group. The lowest poverty rates are found in Western Equatoria (education, public an dprivate assets) and Upper Nile (consumption) (Table 8, panel B).

\section{Multidimensional poverty}

The multidimensional analysis of poverty among adults (results summarized in Table 9) shows that multidimensional poverty, as measured by the adjusted heacount ratio $(\mathrm{k}>=2)$, 
is higher in South Sudan than in Sudan. This is mainly explained by the higher incidence rate of $73 \%$ in South Sudan, compared to $49 \%$ in Sudan, not by the average intensity of poverty among the poor, which is very similar across countries. The dimensional breakdown, indicates that private assets and education are the dimensions that contribute the most to national poverty in Sudan and South Sudan, respectively.

The sub-group poverty profiles by area of residence are higher among adults residing in the rural areas of each country. The cross-country comparison of rural poverty indicates that prevalence of multidimensional poverty is higher among South-Sudanese adults residing in rural areas compared to Sudanese ones. Khartoum and Western Equatoria, on the one side, and that Western Darfur and Jonglei, on the other side, are the states with the lowest and highest multidimensional poverty values in Sudan and South Sudan respectively (Table 9, panel A).

Table 9: Multidimensional poverty profiles

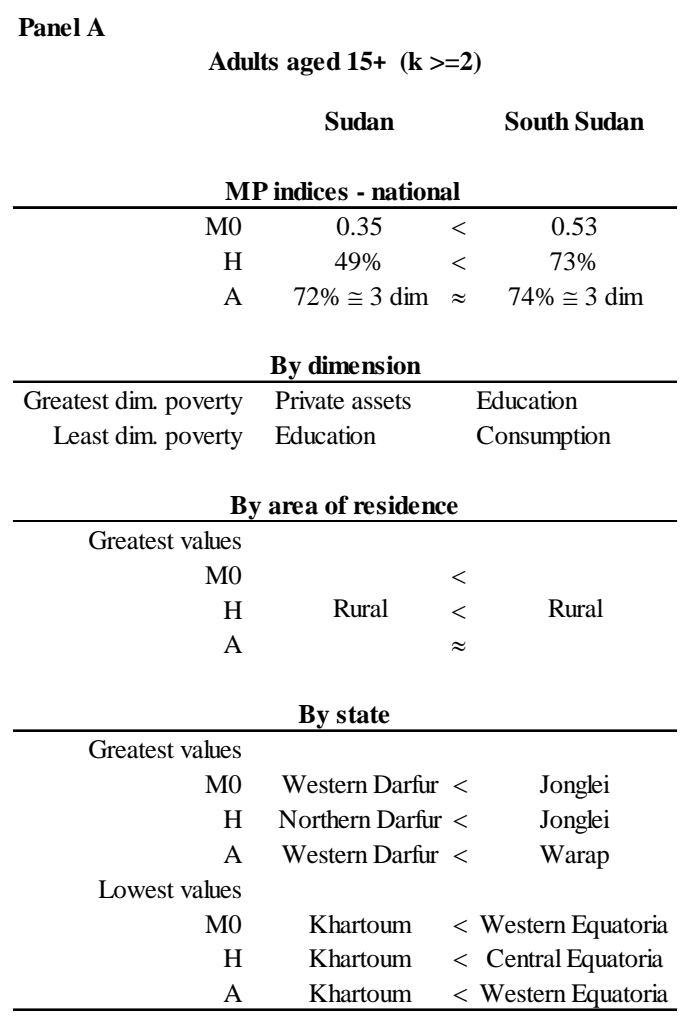



Child multidimensional poverty is also greater among South Sudanese children compared to Sudanese ones, mainly explained by the higher incidence rate of $70 \%$ in South Sudan, compared to 59\% in Sudan. Public assets and private assets are the dimensions that contribute most to national poverty in Sudan and South Sudan, respectively. As with the adult group, education and consumption contribute least to poverty in the same two countries. Multidimensional poverty is higher among children residing in the rural areas. 
The smallest multidimensional poverty values in Sudan and South Sudan are found in Khartoum and Western Equatoria, respectively, while the largest values are found in Western Darfur and Warap, respectively. These states are also among those found as the states with the lowest/highest unidimensional poverty rates (Table 9, panel B).

These unidimensional and multidimensional poverty profiles provide a clear portrait of the dimensional and multidimensional importance of poverty, both for adults and children. The poverty analysis shows important regional and sub-population differences in unidimensional and multidimensional poverty in Sudan and South Sudan. Policy guidance aimed at reducing poverty in each of the two countries would benefit from taking into account such poverty profile differences across gender, age groups, geographical areas and dimensions of welfare.

\section{VII . Conclusion}

The assessment of multidimensional poverty in Sudan and South Sudan show regional and sub-population differences in the unidimensional and multidimensional poverty status of people in both countries. Poverty in Sudan is generally less severe than in South Sudan, with a pattern showing i) lesser unidimensional incidence of poverty, ii) lower multidimensional poverty indices and prevalence, but similar breadth, both for adults and children. This pattern also points towards Khartoum and Western Equatoria as the states with the least poverty, and Northern Darfur, and Warap as the states with the greatest poverty, both for adults and children, in Sudan and South Sudan, respectively. Policy intended at reducing poverty in each of the two countries should recognize the poverty profile differences across age groups, geographical areas and dimensions 


\section{Appendices}

\section{Appendix A.1 - MCA on indicators of public assets}

Table A.1 reports the main statistics of the MCA on public assets in each country. From column 2, we observe that in both countries the masses are evenly distributed across the four indicators, that is, around $25 \%$ of the marginal distribution (mass) corresponds to each of these four indicators. By category, the categories with the largest masses in South Sudan are no toilet facility, burning, firewood/candle wax/solar power, hand pump, and borehole; whereas in Sudan the categories with the largest masses are boreholes, gas/private/public electricity, latrine, and burning. This corroborates the descriptive analysis of public assets in which households in Sudan are better off in their access to and quality of public assets compared to households in South Sudan.

Regargingthe percentage of inertia, the Sudanese indicators with the largest percentage of inertia $^{17}$ are water filtering $(0.16)$, private/shared/bucket toilet $(0.12)$, no toilet facility (0.12), and bin (0.13). In South Sudan, the indicators with the largest percentage of inertia are latrine (0.25), gas/private/public electricity (0.15), heap or pit (0.13), and water filtering (0.08). As described in the descriptive section, these indicators are the less frequent type/source of public assets used by households in each country. This reflects their largest variability or percentage of inertia.

${ }^{17}$ Expressed as a number between 0 and 1, where 1 corresponds to $100 \%$. 
Table A.1: MCA on indicators of public assets - Burt Matrix Statistics in standard normalisation

Sudan South Sudan

Categories

Mass Overall \% of Mass Overall \% of quality inertia quality inertia

Source of drinking water

Water filtering

Boreholes

Hand pump

Running open water

quality inertia

Water vendor

\begin{tabular}{|c|c|c|c|c|c|}
\hline Wf & $99 \%$ & $16 \%$ & $0 \%$ & $83 \%$ & $9 \%$ \\
\hline $10 \%$ & $83 \%$ & $1 \%$ & $9 \%$ & $90 \%$ & $5 \%$ \\
\hline $2 \%$ & $88 \%$ & $4 \%$ & $9 \%$ & $83 \%$ & $3 \%$ \\
\hline $2 \%$ & $81 \%$ & $4 \%$ & $6 \%$ & $55 \%$ & $2 \%$ \\
\hline $5 \%$ & $61 \%$ & $1 \%$ & $1 \%$ & $49 \%$ & $2 \%$ \\
\hline $25 \%$ & & $26 \%$ & $25 \%$ & & $=0 /$ \\
\hline
\end{tabular}

\section{Source of lighting}

Gas, private or public electricity $\quad$ Gs $\quad 11 \% \quad 93 \% \quad 16 \% \quad 1 \% \quad 75 \% \quad 15 \%$

$\begin{array}{llllllll}\text { Paraffin, grass, biogas } & \mathrm{Pa} & 7 \% & 92 \% & 7 \% & 7 \% & 95 \% & 6 \%\end{array}$

Firewood, candle wax, solar power Fc $\quad 3 \% \quad 85 \% \quad 4 \% \quad 11 \% \quad 47 \% \quad 2 \%$

No lighting



Main type of toilet facitily

\begin{tabular}{|c|c|c|c|c|c|c|c|}
\hline Latrine & $\mathrm{La}$ & $15 \%$ & $72 \%$ & $2 \%$ & $5 \%$ & $79 \%$ & $25 \%$ \\
\hline Private, shared or bucket toilet & Sh & $2 \%$ & $95 \%$ & $12 \%$ & $0 \%$ & $86 \%$ & $2 \%$ \\
\hline No toilet facility & $\mathrm{Nt}$ & $8 \%$ & $91 \%$ & $12 \%$ & $20 \%$ & $80 \%$ & $6 \%$ \\
\hline
\end{tabular}

Main method for solid disposal

Bin

$\begin{array}{lllllll}\text { Bin } & 7 \% & 95 \% & 13 \% & 1 \% & 61 \% & 2 \%\end{array}$

Heap or pit He $\quad 7 \% \quad 97 \% \quad 3 \% \quad 6 \% \quad 81 \% \quad 13 \%$

Burning or other

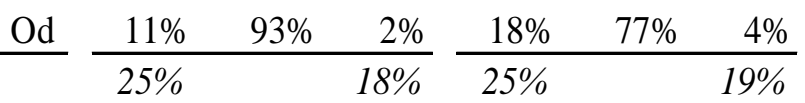

Note: The masses and \% of inertia of categories across all variables add up to $100 \%$. 


\section{Appendix A.2 - MCA on indicators of private assets}

Table A.2 : MCA on indicators of private assets - Burt Matrix Statistics in standard normalisation

\begin{tabular}{|c|c|c|c|c|c|c|c|}
\hline \multirow[b]{2}{*}{ Categories } & & \multicolumn{3}{|c|}{ Sudan } & \multicolumn{3}{|c|}{ South Sudan } \\
\hline & & Mass & $\begin{array}{l}\text { Overall } \\
\text { quality }\end{array}$ & $\begin{array}{c}\% \text { of } \\
\text { inertia }\end{array}$ & Mass & $\begin{array}{c}\text { Overall } \\
\text { quality }\end{array}$ & $\begin{array}{c}\% \text { of } \\
\text { inertia }\end{array}$ \\
\hline \multicolumn{8}{|c|}{ Motor vehicle } \\
\hline Owning & $\mathrm{Y}$ & $1 \%$ & $100 \%$ & $6 \%$ & $0.2 \%$ & $100 \%$ & $8 \%$ \\
\hline \multirow[t]{2}{*}{ Not owning } & $\mathrm{N}$ & $10 \%$ & $100 \%$ & $1 \%$ & $11 \%$ & $100 \%$ & $0.2 \%$ \\
\hline & & $11 \%$ & & $7 \%$ & $11 \%$ & & $9 \%$ \\
\hline \multicolumn{8}{|c|}{ Motor cycle/moto } \\
\hline Owning & $\mathrm{Y}$ & $0.3 \%$ & $96 \%$ & $1 \%$ & $0.4 \%$ & $96 \%$ & $6 \%$ \\
\hline \multirow{2}{*}{ Not owning } & $\mathrm{N}$ & $11 \%$ & $95 \%$ & $0 \%$ & $11 \%$ & $95 \%$ & $0.2 \%$ \\
\hline & & $11 \%$ & & $1 \%$ & $11 \%$ & & $6 \%$ \\
\hline \multicolumn{8}{|l|}{ Bycicle } \\
\hline Owning & $\mathrm{Y}$ & $1 \%$ & $70 \%$ & $1 \%$ & $3 \%$ & $83 \%$ & $3 \%$ \\
\hline \multirow[t]{2}{*}{ Not owning } & $\mathrm{N}$ & $10 \%$ & $70 \%$ & $0.1 \%$ & $8 \%$ & $83 \%$ & $1 \%$ \\
\hline & & $11 \%$ & & $1 \%$ & $11 \%$ & & $4 \%$ \\
\hline \multicolumn{8}{|l|}{ Television } \\
\hline Ownin & $\mathrm{Y}$ & $4 \%$ & $88 \%$ & $13 \%$ & $1 \%$ & $90 \%$ & $17 \%$ \\
\hline \multirow[t]{2}{*}{ Not owning } & $\mathrm{N}$ & $7 \%$ & $88 \%$ & $8 \%$ & $11 \%$ & $90 \%$ & $1 \%$ \\
\hline & & $11 \%$ & & $21 \%$ & $11 \%$ & & $18 \%$ \\
\hline \multicolumn{8}{|l|}{ Telephone } \\
\hline Owning & $\mathrm{Y}$ & $6 \%$ & $93 \%$ & $6 \%$ & $2 \%$ & $88 \%$ & $12 \%$ \\
\hline \multirow[t]{2}{*}{ Not owning } & $\mathrm{N}$ & $5 \%$ & $93 \%$ & $7 \%$ & $9 \%$ & $88 \%$ & $3 \%$ \\
\hline & & $11 \%$ & & $13 \%$ & $11 \%$ & & $15 \%$ \\
\hline \multicolumn{8}{|c|}{ Radio/transistor } \\
\hline Owning & $\mathrm{Y}$ & $5 \%$ & $92 \%$ & $1 \%$ & $3 \%$ & $84 \%$ & $10 \%$ \\
\hline \multirow[t]{2}{*}{ Not owning } & $\mathrm{N}$ & $6 \%$ & $92 \%$ & $1 \%$ & $8 \%$ & $84 \%$ & $4 \%$ \\
\hline & & $11 \%$ & & $2 \%$ & $11 \%$ & & $14 \%$ \\
\hline \multicolumn{8}{|c|}{ Refrigerator } \\
\hline Owning & $\mathrm{Y}$ & $3 \%$ & $86 \%$ & $18 \%$ & $0.1 \%$ & $89 \%$ & $14 \%$ \\
\hline \multirow[t]{2}{*}{ Not owning } & $\mathrm{N}$ & $9 \%$ & $86 \%$ & $5 \%$ & $11 \%$ & $89 \%$ & $0.2 \%$ \\
\hline & & $11 \%$ & & $23 \%$ & $11 \%$ & & $14 \%$ \\
\hline \multicolumn{8}{|l|}{ Fan } \\
\hline Owning & $\mathrm{Y}$ & $3 \%$ & $85 \%$ & $17 \%$ & $0.2 \%$ & $89 \%$ & $15 \%$ \\
\hline \multirow[t]{2}{*}{ Not owning } & $\mathrm{N}$ & $8 \%$ & $85 \%$ & $6 \%$ & $11 \%$ & $89 \%$ & $0.2 \%$ \\
\hline & & $11 \%$ & & $23 \%$ & $11 \%$ & & $15 \%$ \\
\hline \multicolumn{8}{|c|}{ Air cooler/conditioner } \\
\hline Owning & $\mathrm{Y}$ & $1 \%$ & $96 \%$ & $10 \%$ & $0 \%$ & $100 \%$ & $5 \%$ \\
\hline Not owning & $\mathrm{N}$ & $10 \%$ & $96 \%$ & $1 \%$ & $11 \%$ & $100 \%$ & $0 \%$ \\
\hline
\end{tabular}

Note: The masses and \% of inertia of categories across all variables add up to $100 \%$. 


\section{Appendix A.3 - Unidimensional poverty incidence rates}

Table A.3.1: Adults aged 15 years of more

\section{Panel A: Sudan}

\begin{tabular}{|c|c|c|c|c|c|c|c|}
\hline & & Head & Count Rati & o (\%) & & & \\
\hline Dimension & Region & Population & Estimate S & tandard & Lower & Upper & Sub-group \\
\hline & & shares & & error & Bound & Bound & Contribution \\
\hline Education & Urban & $39 \%$ & 21.00 & 1.18 & 18.68 & 23.33 & $22 \%$ \\
\hline & Rural & $61 \%$ & 49.86 & 1.32 & 47.28 & 52.45 & $78 \%$ \\
\hline & Population & & 38.30 & 1.20 & 35.93 & 40.66 & \\
\hline Consumption & Urban & $39 \%$ & 22.75 & 1.78 & 19.25 & 26.25 & $22 \%$ \\
\hline & Rural & $61 \%$ & 53.11 & 1.39 & 50.38 & 55.83 & $78 \%$ \\
\hline & Population & & 40.96 & 1.38 & 38.24 & 43.68 & \\
\hline Private assets & Urban & $39 \%$ & 13.97 & 1.35 & 11.32 & 16.62 & $13 \%$ \\
\hline & Rural & $61 \%$ & 60.55 & 1.99 & 56.65 & 64.46 & $87 \%$ \\
\hline & Population & & 41.86 & 1.79 & 38.36 & 45.37 & \\
\hline Public assets & Urban & $39 \%$ & 12.01 & 1.53 & 8.99 & 15.02 & $12 \%$ \\
\hline & Rural & $61 \%$ & 59.87 & 2.23 & 55.49 & 64.24 & $88 \%$ \\
\hline & Population & & 40.71 & 1.93 & 36.93 & 44.50 & \\
\hline
\end{tabular}

\section{Panel B: South Sudan}

\begin{tabular}{|c|c|c|c|c|c|c|c|}
\hline \multirow{3}{*}{ Dimension } & \multirow{3}{*}{ Area } & \multirow{3}{*}{$\begin{array}{c}\text { Population } \\
\text { shares }\end{array}$} & \multicolumn{4}{|c|}{ Head Count Ratio (\%) } & \multirow{3}{*}{$\begin{array}{l}\text { Sub-group } \\
\text { Contribution }\end{array}$} \\
\hline & & & \multicolumn{2}{|c|}{ te Standard } & \multirow{2}{*}{$\begin{array}{l}\text { Lower } \\
\text { Bound }\end{array}$} & \multirow{2}{*}{$\begin{array}{l}\text { Upper } \\
\text { Bound }\end{array}$} & \\
\hline & & & & error & & & \\
\hline \multirow[t]{3}{*}{ Education } & Urban & $14 \%$ & 47.63 & 1.85 & 43.98 & 51.27 & $9 \%$ \\
\hline & Rural & $86 \%$ & 79.05 & 1.04 & 77.01 & 81.09 & $91 \%$ \\
\hline & Population & & 73.77 & 1.06 & 71.67 & 75.86 & \\
\hline \multirow[t]{3}{*}{ Consumption } & Urban & $14 \%$ & 22.55 & 2.12 & 18.39 & 26.71 & $6 \%$ \\
\hline & Rural & $86 \%$ & 54.47 & 1.64 & 51.25 & 57.70 & $94 \%$ \\
\hline & Population & & 49.10 & 1.53 & 46.10 & 52.10 & \\
\hline \multirow[t]{3}{*}{ Private assets } & Urban & $14 \%$ & 17.85 & 2.05 & 13.83 & 21.87 & $4 \%$ \\
\hline & Rural & $86 \%$ & 62.37 & 1.73 & 58.97 & 65.77 & $96 \%$ \\
\hline & Population & & 54.87 & 1.67 & 51.59 & 58.15 & \\
\hline \multirow[t]{3}{*}{ Public assets } & Urban & $14 \%$ & 27.44 & 2.42 & 22.69 & 32.19 & $7 \%$ \\
\hline & Rural & $86 \%$ & 58.77 & 1.99 & 54.85 & 62.69 & $93 \%$ \\
\hline & Population & & 53.50 & 1.82 & 49.93 & 57.06 & \\
\hline
\end{tabular}


Table A.3.2: Unidimensional poverty incidence in the adult population, by State : lower and upper bounds of $\mathbf{9 5 \%}$ confidence intervals for the headcount ratios

\section{Panel A: Sudan}

\begin{tabular}{|c|c|c|c|c|c|}
\hline \multirow[b]{2}{*}{ State } & \multicolumn{4}{|c|}{ Head Count ratio (\%) } & \multirow[b]{2}{*}{$\begin{array}{l}\text { Sub-group } \\
\text { Contribution }\end{array}$} \\
\hline & Estimate $S$ & $\begin{array}{l}\text { tand. } \\
\text { error }\end{array}$ & $\begin{array}{l}\text { Lower } \\
\text { Bound }\end{array}$ & $\begin{array}{l}\text { Upper } \\
\text { Bound }\end{array}$ & \\
\hline \multicolumn{6}{|l|}{ Education } \\
\hline Northern & 25.3 & 1.5 & 22.3 & 28.3 & $2 \%$ \\
\hline River Nile & 28.9 & 3.0 & 23.1 & 34.7 & $3 \%$ \\
\hline Red Sea & 41.7 & 4.5 & 32.9 & 50.4 & $2 \%$ \\
\hline Kassala & 54.7 & 4.6 & 45.7 & 63.8 & $8 \%$ \\
\hline Al-Gadarif & 50.5 & 4.5 & 41.7 & 59.4 & $6 \%$ \\
\hline Khartoum & 19.3 & 2.2 & 14.9 & 23.6 & $11 \%$ \\
\hline Al-Gezira & 35.7 & 3.3 & 29.2 & 42.2 & $12 \%$ \\
\hline White Nile & 39.4 & 3.7 & 32.1 & 46.7 & $6 \%$ \\
\hline Sinnar & 45.0 & 3.7 & 37.7 & 52.3 & $5 \%$ \\
\hline Blue Nile & 53.9 & 3.9 & 46.2 & 61.6 & $4 \%$ \\
\hline Northern Kordofar & 50.7 & 3.7 & 43.4 & 58.0 & $11 \%$ \\
\hline Southern Kordofar & 50.6 & 3.0 & 44.7 & 56.5 & $7 \%$ \\
\hline Northern Darfur & 38.7 & 2.3 & 34.2 & 43.2 & $5 \%$ \\
\hline Western Darfur & 55.3 & 4.2 & 47.0 & 63.6 & $5 \%$ \\
\hline Southern Darfur & 43.1 & 3.2 & 36.7 & 49.5 & $13 \%$ \\
\hline Population & 38.3 & 1.2 & 35.9 & 40.7 & \\
\hline \multicolumn{6}{|l|}{ Consumption } \\
\hline Northern & 32.5 & 3.1 & 26.4 & 38.5 & $2 \%$ \\
\hline River Nile & 29.9 & 3.2 & 23.6 & 36.1 & $3 \%$ \\
\hline Red Sea & 44.0 & 4.1 & 35.9 & 52.1 & $2 \%$ \\
\hline Kassala & 32.8 & 4.5 & 24.0 & 41.5 & $5 \%$ \\
\hline Al-Gadarif & 44.2 & 3.9 & 36.4 & 51.9 & $5 \%$ \\
\hline Khartoum & 22.3 & 2.8 & 16.8 & 27.9 & $12 \%$ \\
\hline Al-Gezira & 33.3 & 3.5 & 26.4 & 40.2 & $10 \%$ \\
\hline White Nile & 52.6 & 4.1 & 44.6 & 60.5 & $8 \%$ \\
\hline Sinnar & 41.1 & 3.6 & 34.1 & 48.1 & $4 \%$ \\
\hline Blue Nile & 52.3 & 3.5 & 45.4 & 59.2 & $3 \%$ \\
\hline Northern Kordofar & 52.4 & 4.8 & 43.0 & 61.7 & $10 \%$ \\
\hline Southern Kordofar & 57.7 & 3.8 & 50.1 & 65.2 & $7 \%$ \\
\hline Northern Darfur & 69.1 & 3.0 & 63.2 & 75.0 & $8 \%$ \\
\hline Western Darfur & 48.9 & 5.4 & 38.3 & 59.5 & $4 \%$ \\
\hline Southern Darfur & 53.4 & 4.8 & 44.0 & 62.8 & $15 \%$ \\
\hline Population & 41.0 & 1.4 & 38.2 & 43.7 & \\
\hline
\end{tabular}

\begin{tabular}{cc}
\hline \multirow{2}{*}{ State } & Head Count ratio (\%) \\
\cline { 2 - 2 } & $\begin{array}{r}\text { Estimate Stand. Lower Upper Sub-group } \\
\text { error Bound Bound Contribution }\end{array}$
\end{tabular}

Private Assets

\begin{tabular}{lccrcc} 
Northern & 18.8 & 2.5 & 13.8 & 23.8 & $1 \%$ \\
River Nile & 30.7 & 4.1 & 22.7 & 38.7 & $3 \%$ \\
Red Sea & 46.1 & 6.1 & 34.2 & 58.0 & $2 \%$ \\
Kassala & 58.9 & 6.3 & 46.6 & 71.2 & $8 \%$ \\
Al-Gadarif & 48.0 & 4.8 & 38.5 & 57.5 & $5 \%$ \\
Khartoum & 11.2 & 2.4 & 6.4 & 15.9 & $6 \%$ \\
Al-Gezira & 28.4 & 4.5 & 19.5 & 37.3 & $9 \%$ \\
White Nile & 50.3 & 5.0 & 40.4 & 60.1 & $7 \%$ \\
Sinnar & 48.1 & 5.0 & 38.3 & 58.0 & $5 \%$ \\
Blue Nile & 52.3 & 5.3 & 41.9 & 62.6 & $3 \%$ \\
Northern Kordofar & 63.7 & 4.5 & 54.9 & 72.5 & $12 \%$ \\
Southern Kordofar & 55.3 & 4.3 & 46.8 & 63.7 & $7 \%$ \\
White Nile & 74.7 & 4.0 & 66.8 & 82.6 & $9 \%$ \\
Sinnar & 71.5 & 6.5 & 58.7 & 84.4 & $6 \%$ \\
Southern Darfur & 58.3 & 6.2 & 46.2 & 70.5 & $16 \%$ \\
Population & $\mathbf{4 1 . 9}$ & $\mathbf{1 . 8}$ & $\mathbf{3 8 . 4}$ & $\mathbf{4 5 . 4}$ & \\
\hline
\end{tabular}

Public Assets

$\begin{array}{lrrrrc}\text { Northern } & 8.2 & 1.8 & 4.6 & 11.8 & 1 \% \\ \text { River Nile } & 16.2 & 3.6 & 9.2 & 23.2 & 2 \% \\ \text { Red Sea } & 26.5 & 5.0 & 16.7 & 36.4 & 1 \% \\ \text { Kassala } & 58.5 & 6.7 & 45.3 & 71.6 & 8 \% \\ \text { Al-Gadarif } & 52.3 & 5.8 & 40.9 & 63.7 & 6 \% \\ \text { Khartoum } & 8.7 & 2.9 & 2.9 & 14.5 & 5 \% \\ \text { Al-Gezira } & 31.8 & 5.9 & 20.1 & 43.5 & 10 \% \\ \text { White Nile } & 49.2 & 6.1 & 37.3 & 61.2 & 8 \% \\ \text { Sinnar } & 47.1 & 6.6 & 34.1 & 60.1 & 5 \% \\ \text { Blue Nile } & 52.3 & 5.5 & 41.6 & 63.0 & 4 \% \\ \text { Northern Kordofar } & 70.5 & 5.8 & 59.1 & 81.9 & 14 \% \\ \text { Southern Kordofar } & 77.8 & 4.4 & 69.2 & 86.5 & 9 \% \\ \text { Northern Darfur } & 49.2 & 3.6 & 42.1 & 56.3 & 6 \% \\ \text { Western Darfur } & 76.9 & 5.3 & 66.5 & 87.3 & 7 \% \\ \text { Southern Darfur } & 54.4 & 4.9 & 44.7 & 64.0 & 15 \% \\ \text { Population } & 40.7 & \mathbf{1 . 9} & 36.9 & \mathbf{4 4 . 5} & \\ & & & & & \end{array}$




\section{Panel B: South Sudan}

\begin{tabular}{|c|c|c|c|c|c|c|c|c|c|c|c|}
\hline \multirow[b]{2}{*}{ State } & \multicolumn{4}{|c|}{ Head Count ratio (\%) } & \multirow[b]{2}{*}{$\begin{array}{c}\text { Sub-group } \\
\text { Contribution } \\
\end{array}$} & \multirow[b]{2}{*}{ State } & \multicolumn{4}{|c|}{ Head Count ratio (\%) } & \multirow[b]{2}{*}{$\begin{array}{l}\text { Sub-group } \\
\text { Contributior }\end{array}$} \\
\hline & Estimate & $\begin{array}{c}\text { Stand. } \\
\text { error }\end{array}$ & $\begin{array}{l}\text { Lower } \\
\text { Bound }\end{array}$ & $\begin{array}{l}\text { Upper } \\
\text { Bound } \\
\end{array}$ & & & Estimate & $\begin{array}{l}\text { ertand. } \\
\text { error }\end{array}$ & $\begin{array}{l}\text { Lower } \\
\text { Bound }\end{array}$ & $\begin{array}{l}\text { Upper } \\
\text { Bound } \\
\end{array}$ & \\
\hline Education & & & & & & Private Assets & & & & & \\
\hline Upper Nile & 56.0 & 2.4 & 51.2 & 60.8 & $8 \%$ & Upper Nile & 51.7 & 5.6 & 40.7 & 62.6 & $10 \%$ \\
\hline Jonglei & 84.4 & 1.9 & 80.6 & 88.2 & $17 \%$ & Jonglei & 78.3 & 3.7 & 71.1 & 85.5 & $21 \%$ \\
\hline Unity & 75.3 & 2.1 & 71.1 & 79.5 & $5 \%$ & Unity & 55.2 & 4.5 & 46.3 & 64.0 & $5 \%$ \\
\hline Warap & 84.6 & 2.1 & 80.5 & 88.7 & $15 \%$ & Warap & 67.7 & 3.4 & 61.0 & 74.3 & $16 \%$ \\
\hline North.B.Al Ghaza] & 80.4 & 1.8 & 76.8 & 84.0 & $11 \%$ & North.B.Al Ghazal & 53.5 & 3.4 & 46.9 & 60.1 & $10 \%$ \\
\hline West.B.Al Ghazal & 66.8 & 3.7 & 59.4 & 74.2 & $4 \%$ & West.B.Al Ghazal & 28.8 & 4.0 & 21.1 & 36.6 & $2 \%$ \\
\hline Lakes & 83.2 & 2.4 & 78.5 & 87.8 & $8 \%$ & Lakes & 46.7 & 4.8 & 37.4 & 56.1 & $6 \%$ \\
\hline Western Equatoria & 67.9 & 2.4 & 63.3 & 72.6 & $8 \%$ & Western Equatoria & 29.8 & 2.9 & 24.1 & 35.4 & $5 \%$ \\
\hline Central Equatoria & 55.9 & 3.6 & 48.7 & 63.1 & $10 \%$ & Central Equatoria & 32.7 & 4.6 & 23.6 & 41.8 & $8 \%$ \\
\hline Eastern Equatoria & 81.3 & 3.4 & 74.7 & 87.9 & $13 \%$ & Eastern Equatoria & 74.7 & 4.1 & 66.7 & 82.7 & $16 \%$ \\
\hline Population & 73.8 & 1.1 & 71.7 & 75.9 & & Population & 54.9 & 1.7 & 51.6 & 58.1 & \\
\hline Consumption & & & & & & Public Assets & & & & & \\
\hline Upper Nile & 26.0 & 4.2 & 17.8 & 34.3 & $6 \%$ & Upper Nile & 58.6 & 4.4 & 50.0 & 67.2 & $12 \%$ \\
\hline Jonglei & 46.4 & 3.8 & 38.9 & 54.0 & $14 \%$ & Jonglei & 78.4 & 3.1 & 72.3 & 84.4 & $21 \%$ \\
\hline Unity & 66.6 & 3.9 & 58.9 & 74.3 & $7 \%$ & Unity & 55.7 & 5.0 & 45.9 & 65.5 & $6 \%$ \\
\hline Warap & 63.8 & 3.8 & 56.2 & 71.3 & $17 \%$ & Warap & 78.2 & 3.4 & 71.4 & 84.9 & $19 \%$ \\
\hline North.B.Al Ghaza] & 74.5 & 3.0 & 68.7 & 80.3 & $15 \%$ & North.B.Al Ghazal & 61.8 & 3.4 & 55.2 & 68.5 & $12 \%$ \\
\hline West.B.Al Ghazal & 39.6 & 3.6 & 32.5 & 46.7 & $4 \%$ & West.B.Al Ghazal & 49.5 & 4.7 & 40.3 & 58.7 & $4 \%$ \\
\hline Lakes & 49.2 & 4.5 & 40.4 & 57.9 & $7 \%$ & Lakes & 47.8 & 3.4 & 41.1 & 54.4 & $6 \%$ \\
\hline Western Equatoria & 39.6 & 3.2 & 33.4 & 45.9 & $7 \%$ & Western Equatoria & 10.0 & 3.4 & 3.3 & 16.7 & $2 \%$ \\
\hline Central Equatoria & 40.3 & 5.0 & 30.4 & 50.2 & $11 \%$ & Central Equatoria & 15.2 & 3.3 & 8.7 & 21.6 & $4 \%$ \\
\hline Eastern Equatoria & 47.2 & 3.6 & 40.1 & 54.2 & $11 \%$ & Eastern Equatoria & 59.1 & 4.3 & 50.6 & 67.5 & $13 \%$ \\
\hline Population & 49.1 & 1.5 & 46.1 & 52.1 & & Population & 53.5 & 1.8 & 49.9 & 57.1 & \\
\hline
\end{tabular}


Table A.3.3: Children aged 6 to 14 years

\section{Panel A: Sudan}

\begin{tabular}{|c|c|c|c|c|c|c|}
\hline \multirow{3}{*}{ Region } & \multirow{3}{*}{$\begin{array}{c}\text { Population } \\
\text { shares }\end{array}$} & \multicolumn{4}{|c|}{ Head Count Ratio (\%) } & \multirow{3}{*}{$\begin{array}{l}\text { Sub-group } \\
\text { Contribution }\end{array}$} \\
\hline & & \multicolumn{2}{|c|}{ te Standard } & \multirow{2}{*}{$\begin{array}{l}\text { Lower } \\
\text { Bound }\end{array}$} & \multirow{2}{*}{$\begin{array}{l}\text { Upper } \\
\text { Bound }\end{array}$} & \\
\hline & & & error & & & \\
\hline Urban & $34 \%$ & 14.41 & 1.19 & 12.08 & 16.74 & $16 \%$ \\
\hline Rural & $66 \%$ & 38.22 & 1.31 & 35.66 & 40.79 & $84 \%$ \\
\hline Population & & 30.18 & 1.12 & 27.98 & 32.38 & \\
\hline Urban & $34 \%$ & 33.27 & 2.50 & 28.36 & 38.19 & $20 \%$ \\
\hline Rural & $66 \%$ & 65.92 & 1.45 & 63.07 & 68.77 & $80 \%$ \\
\hline Population & & 54.90 & 1.48 & 51.99 & 57.81 & \\
\hline Urban & $34 \%$ & 19.69 & 1.84 & 16.08 & 23.30 & $13 \%$ \\
\hline Rural & $66 \%$ & 67.70 & 1.81 & 64.15 & 71.25 & $87 \%$ \\
\hline Population & & 51.44 & 1.81 & 47.88 & 54.99 & \\
\hline Urban & $34 \%$ & 17.36 & 2.11 & 13.21 & 21.51 & $11 \%$ \\
\hline Rural & $66 \%$ & 74.28 & 1.99 & 70.37 & 78.19 & $89 \%$ \\
\hline Population & & 55.06 & 2.09 & 50.96 & 59.16 & \\
\hline
\end{tabular}

\section{Panel B: South Sudan}

\begin{tabular}{lcccccc}
\hline Urban & $14 \%$ & 31.38 & 2.60 & 26.27 & 36.50 & $8 \%$ \\
Rural & $86 \%$ & 58.67 & 1.82 & 55.11 & 62.24 & $92 \%$ \\
Population & & $\mathbf{5 4 . 7 2}$ & $\mathbf{1 . 6 4}$ & $\mathbf{5 1 . 5 1}$ & $\mathbf{5 7 . 9 3}$ & \\
& & & & & & \\
Urban & $14 \%$ & 25.87 & 2.34 & 21.26 & 30.47 & $7 \%$ \\
Rural & $86 \%$ & 56.24 & 1.84 & 52.63 & 59.85 & $93 \%$ \\
Population & & $\mathbf{5 1 . 8 4}$ & $\mathbf{1 . 6 6}$ & $\mathbf{4 8 . 5 7}$ & $\mathbf{5 5 . 1 1}$ & \\
& & & & & & \\
Urban & $14 \%$ & 21.07 & 2.73 & 15.71 & 26.44 & $5 \%$ \\
Rural & $86 \%$ & 63.54 & 1.86 & 59.88 & 67.20 & $95 \%$ \\
Population & & $\mathbf{5 7 . 3 8}$ & $\mathbf{1 . 7 6}$ & $\mathbf{5 3 . 9 2}$ & $\mathbf{6 0 . 8 5}$ & \\
& & & & & & \\
Urban & $14 \%$ & 30.38 & 2.79 & 24.89 & 35.87 & $8 \%$ \\
Rural & $86 \%$ & 59.52 & 2.08 & 55.43 & 63.61 & $92 \%$ \\
Population & & $\mathbf{5 5 . 2 9}$ & $\mathbf{1 . 8 8}$ & $\mathbf{5 1 . 5 9}$ & $\mathbf{5 9 . 0 0}$ & \\
\hline
\end{tabular}


Table A.3.4: Unidimensional poverty incidence among children aged 6 to 14 years, by State: lower and upper bounds of $\mathbf{9 5 \%}$ confidence intervals for the headcount ratios

\section{Panel A: Sudan}

\begin{tabular}{|c|c|c|c|c|c|c|c|c|c|c|c|}
\hline \multirow[b]{2}{*}{ State } & \multicolumn{4}{|c|}{ Head Count ratio (\%) } & \multirow[b]{2}{*}{$\begin{array}{l}\text { Sub-group } \\
\text { Contribution }\end{array}$} & \multirow[b]{2}{*}{ State } & \multicolumn{4}{|c|}{ Head Count ratio (\%) } & \multirow[b]{2}{*}{$\begin{array}{c}\text { Sub-group } \\
\text { Contribution }\end{array}$} \\
\hline & Estimate & $\begin{array}{c}\text { Stand. } \\
\text { error }\end{array}$ & $\begin{array}{l}\text { Lower } \\
\text { Bound }\end{array}$ & $\begin{array}{l}\text { Upper } \\
\text { Bound }\end{array}$ & & & $\overline{\text { Estimate S }}$ & $\begin{array}{l}\text { tand. } \\
\text { error }\end{array}$ & $\begin{array}{l}\text { Lower } \\
\text { Bound }\end{array}$ & $\begin{array}{l}\text { Upper } \\
\text { Bound }(\end{array}$ & \\
\hline Education & & & & & & Private Assets & & & & & \\
\hline Northern & 16.4 & 1.7 & 13.0 & 19.8 & $1 \%$ & Northern & 24.1 & 3.5 & 17.3 & 30.9 & $1 \%$ \\
\hline River Nile & 15.1 & 3.4 & 8.4 & 21.8 & $2 \%$ & River Nile & 41.2 & 6.1 & 29.1 & 53.2 & $3 \%$ \\
\hline Red Sea & 23.3 & 3.9 & 15.7 & 30.9 & $1 \%$ & Red Sea & 55.8 & 6.6 & 42.8 & 68.9 & $2 \%$ \\
\hline Kassala & 48.8 & 6.1 & 36.8 & 60.8 & $9 \%$ & Kassala & 67.4 & 5.9 & 55.9 & 79.0 & $8 \%$ \\
\hline Al-Gadarif & 38.3 & 4.6 & 29.3 & 47.3 & $7 \%$ & Al-Gadarif & 52.6 & 4.9 & 42.9 & 62.2 & $5 \%$ \\
\hline Khartoum & 13.2 & 2.1 & 9.0 & 17.4 & $7 \%$ & Khartoum & 17.0 & 3.7 & 9.7 & 24.2 & $5 \%$ \\
\hline Al-Gezira & 25.0 & 2.6 & 19.9 & 30.1 & $10 \%$ & Al-Gezira & 32.5 & 5.3 & 22.2 & 42.9 & $7 \%$ \\
\hline White Nile & 29.5 & 3.8 & 22.0 & 36.9 & $6 \%$ & White Nile & 52.2 & 4.8 & 42.7 & 61.7 & $6 \%$ \\
\hline Sinnar & 36.7 & 4.2 & 28.3 & 45.0 & $5 \%$ & Sinnar & 54.8 & 5.2 & 44.6 & 65.1 & $4 \%$ \\
\hline Blue Nile & 30.7 & 3.2 & 24.5 & 37.0 & $3 \%$ & Blue Nile & 59.9 & 4.8 & 50.5 & 69.3 & $4 \%$ \\
\hline Northern Kordofan & 39.4 & 3.8 & 31.9 & 46.8 & $12 \%$ & Northern Kordofan & 68.5 & 4.3 & 60.0 & 77.0 & $12 \%$ \\
\hline Southern Kordofan & 38.1 & 3.4 & 31.3 & 44.8 & $7 \%$ & Southern Kordofan & 62.4 & 4.0 & 54.5 & 70.3 & $7 \%$ \\
\hline Northern Darfur & 25.9 & 2.5 & 20.9 & 30.8 & $5 \%$ & White Nile & 74.2 & 4.0 & 66.4 & 82.1 & $8 \%$ \\
\hline Western Darfur & 42.4 & 3.9 & 34.8 & 50.0 & $6 \%$ & Sinnar & 78.4 & 5.1 & 68.4 & 88.5 & $7 \%$ \\
\hline Southern Darfur & 36.1 & 3.4 & 29.4 & 42.7 & $18 \%$ & Southern Darfur & 68.0 & 5.5 & 57.2 & 78.7 & $20 \%$ \\
\hline Population & 30.2 & 1.1 & 28.0 & 32.4 & & Population & 51.4 & 1.8 & 47.9 & 55.0 & \\
\hline Consumption & & & & & & Public Assets & & & & & \\
\hline Northern & 45.1 & 3.7 & 37.9 & 52.4 & $2 \%$ & Northern & 14.1 & 3.3 & 7.6 & 20.7 & $1 \%$ \\
\hline River Nile & 39.2 & 4.5 & 30.4 & 48.0 & $2 \%$ & River Nile & 28.8 & 5.9 & 17.2 & 40.4 & $2 \%$ \\
\hline Red Sea & 59.4 & 4.7 & 50.3 & 68.6 & $2 \%$ & Red Sea & 32.6 & 4.8 & 23.2 & 42.1 & $1 \%$ \\
\hline Kassala & 41.7 & 5.1 & 31.8 & 51.7 & $4 \%$ & Kassala & 68.3 & 6.2 & 56.2 & 80.4 & $7 \%$ \\
\hline Al-Gadarif & 60.0 & 4.1 & 52.0 & 68.0 & $6 \%$ & Al-Gadarif & 62.5 & 5.9 & 50.9 & 74.0 & $6 \%$ \\
\hline Khartoum & 33.4 & 4.1 & 25.3 & 41.4 & $10 \%$ & Khartoum & 15.7 & 4.8 & 6.3 & 25.1 & $5 \%$ \\
\hline Al-Gezira & 46.6 & 4.4 & 37.9 & 55.2 & $10 \%$ & Al-Gezira & 38.8 & 6.8 & 25.4 & 52.3 & $8 \%$ \\
\hline White Nile & 60.0 & 4.9 & 50.5 & 69.6 & $7 \%$ & White Nile & 55.0 & 6.2 & 42.8 & 67.3 & $6 \%$ \\
\hline Sinnar & 50.7 & 4.6 & 41.6 & 59.7 & $4 \%$ & Sinnar & 52.6 & 7.2 & 38.5 & 66.6 & $4 \%$ \\
\hline Blue Nile & 63.5 & 4.3 & 55.1 & 72.0 & $4 \%$ & Blue Nile & 57.2 & 5.3 & 46.8 & 67.6 & $3 \%$ \\
\hline Northern Kordofan & 69.1 & 4.5 & 60.3 & 77.9 & $11 \%$ & Northern Kordofan & 86.0 & 4.5 & 77.2 & 94.8 & $14 \%$ \\
\hline Southern Kordofan & 65.8 & 4.3 & 57.4 & 74.1 & $7 \%$ & Southern Kordofan & 84.3 & 3.7 & 77.0 & 91.7 & $9 \%$ \\
\hline Northern Darfur & 77.4 & 2.9 & 71.6 & 83.2 & $8 \%$ & Northern Darfur & 58.3 & 4.1 & 50.2 & 66.3 & $6 \%$ \\
\hline Western Darfur & 62.5 & 5.5 & 51.7 & 73.3 & $5 \%$ & Western Darfur & 82.5 & 4.7 & 73.3 & 91.6 & $7 \%$ \\
\hline Southern Darfur & 65.4 & 4.3 & 57.0 & 73.7 & $18 \%$ & Southern Darfur & 76.7 & 5.7 & 65.5 & 88.0 & $21 \%$ \\
\hline Population & 54.9 & 1.5 & 52.0 & 57.8 & & Population & 55.1 & 2.1 & 51.0 & 59.2 & \\
\hline
\end{tabular}




\section{Panel B: South Sudan}

\begin{tabular}{|c|c|c|c|c|c|c|c|c|c|c|c|}
\hline \multirow[b]{2}{*}{ State } & \multicolumn{4}{|c|}{ Head Count ratio (\%) } & \multirow[b]{2}{*}{$\begin{array}{c}\text { Sub-group } \\
\text { Contribution } \\
\end{array}$} & \multirow[b]{2}{*}{ State } & \multicolumn{4}{|c|}{ Head Count ratio (\%) } & \multirow[b]{2}{*}{$\begin{array}{c}\text { Sub-group } \\
\text { Contributior }\end{array}$} \\
\hline & Estimate & $\begin{array}{l}\text { Stand. } \\
\text { error }\end{array}$ & $\begin{array}{l}\text { Lower } \\
\text { Bound }\end{array}$ & $\begin{array}{l}\text { Upper } \\
\text { Bound } \\
\end{array}$ & & & Estimate & $\begin{array}{l}\text { Stand. } \\
\text { error } \\
\end{array}$ & $\begin{array}{l}\text { Lower } \\
\text { Bound } \\
\end{array}$ & $\begin{array}{l}\text { Upper } \\
\text { I Bound } \\
\end{array}$ & \\
\hline Education & & & & & & Private Assets & & & & & \\
\hline Upper Nile & 38.7 & 3.3 & 32.1 & 45.3 & $9 \%$ & Upper Nile & 51.7 & 5.2 & 41.5 & 61.8 & $12 \%$ \\
\hline Jonglei & 55.0 & 4.2 & 46.7 & 63.3 & $14 \%$ & Jonglei & 79.7 & 3.9 & 72.0 & 87.4 & $20 \%$ \\
\hline Unity & 58.6 & 4.4 & 49.9 & 67.2 & $7 \%$ & Unity & 55.4 & 4.6 & 46.4 & 64.4 & $6 \%$ \\
\hline Warap & 74.1 & 3.7 & 66.9 & 81.4 & $17 \%$ & Warap & 73.8 & 3.7 & 66.6 & 81.1 & $16 \%$ \\
\hline North.B.Al Ghaza] & 62.9 & 2.9 & 57.2 & 68.6 & $11 \%$ & North.B.Al Ghazal & 55.1 & 3.7 & 47.9 & 62.4 & $9 \%$ \\
\hline West.B.Al Ghazal & 57.9 & 5.4 & 47.3 & 68.5 & $4 \%$ & West.B.Al Ghazal & 33.8 & 4.4 & 25.1 & 42.5 & $2 \%$ \\
\hline Lakes & 65.0 & 4.4 & 56.4 & 73.6 & $10 \%$ & Lakes & 43.0 & 4.8 & 33.5 & 52.5 & $6 \%$ \\
\hline Western Equatoria & 30.4 & 2.8 & 24.8 & 35.9 & $4 \%$ & Western Equatoria & 24.8 & 3.6 & 17.7 & 31.8 & $3 \%$ \\
\hline Central Equatoria & 36.7 & 6.0 & 24.8 & 48.5 & $9 \%$ & Central Equatoria & 39.3 & 5.7 & 28.1 & 50.6 & $9 \%$ \\
\hline Eastern Equatoria & 68.9 & 5.3 & 58.4 & 79.5 & $15 \%$ & Eastern Equatoria & 78.8 & 3.9 & 71.1 & 86.5 & $17 \%$ \\
\hline Population & 54.7 & 1.6 & 51.5 & 57.9 & & Population & 57.4 & 1.8 & 53.9 & 60.8 & \\
\hline Consumption & & & & & & Public Assets & & & & & \\
\hline Upper Nile & 25.3 & 4.3 & 16.8 & 33.8 & $7 \%$ & Upper Nile & 58.0 & 4.9 & 48.3 & 67.7 & $14 \%$ \\
\hline Jonglei & 48.6 & 5.2 & 38.5 & 58.8 & $13 \%$ & Jonglei & 81.1 & 3.0 & 75.2 & 87.1 & $21 \%$ \\
\hline Unity & 69.2 & 3.5 & 62.3 & 76.2 & $8 \%$ & Unity & 56.7 & 4.9 & 47.1 & 66.3 & $6 \%$ \\
\hline Warap & 63.4 & 4.1 & 55.3 & 71.5 & $16 \%$ & Warap & 78.3 & 4.1 & 70.3 & 86.4 & $18 \%$ \\
\hline North.B.Al Ghazal & 77.4 & 2.9 & 71.8 & 83.0 & $14 \%$ & North.B.Al Ghazal & 61.5 & 3.9 & 53.9 & 69.1 & $10 \%$ \\
\hline West.B.Al Ghazal & 47.8 & 3.8 & 40.4 & 55.2 & $3 \%$ & West.B.Al Ghazal & 54.7 & 5.4 & 44.0 & 65.3 & $4 \%$ \\
\hline Lakes & 48.3 & 4.7 & 39.1 & 57.5 & $8 \%$ & Lakes & 48.7 & 3.5 & 41.8 & 55.6 & $7 \%$ \\
\hline Western Equatoria & 47.0 & 3.7 & 39.6 & 54.3 & $7 \%$ & Western Equatoria & 8.9 & 3.2 & 2.6 & 15.3 & $1 \%$ \\
\hline Central Equatoria & 48.0 & 5.4 & 37.4 & 58.7 & $12 \%$ & Central Equatoria & 17.8 & 3.7 & 10.4 & 25.1 & $4 \%$ \\
\hline Eastern Equatoria & 54.6 & 3.9 & 47.0 & 62.3 & $13 \%$ & Eastern Equatoria & 64.7 & 4.4 & 56.0 & 73.3 & $14 \%$ \\
\hline Population & 51.8 & 1.7 & 48.6 & 55.0 & & Population & 55.3 & 1.9 & 51.6 & 59.0 & \\
\hline
\end{tabular}




\section{Appendix A.4 - Multidimensional poverty indices: M0, H, and A}

\section{Table A.4.1: Adults aged 15 years of more}

\section{Panel A: Sudan}

\begin{tabular}{|c|c|c|c|c|c|c|c|c|c|c|c|c|c|c|c|c|}
\hline \multirow[t]{3}{*}{ Group } & \multicolumn{4}{|c|}{$\mathbf{k}=1$ - Union } & \multicolumn{4}{|c|}{$\mathbf{k}=2$} & \multicolumn{4}{|c|}{$\mathbf{k}=3$} & \multicolumn{4}{|c|}{$k=4$ - Intersection } \\
\hline & \multirow[t]{2}{*}{$\mathbf{H}$} & \multirow[t]{2}{*}{$\mathbf{A}$} & \multicolumn{2}{|c|}{ Mo } & \multirow[t]{2}{*}{$\mathbf{H}$} & \multirow[t]{2}{*}{ A } & \multicolumn{2}{|c|}{ Mo } & \multirow[t]{2}{*}{$\mathbf{H}$} & \multirow[t]{2}{*}{ A } & \multicolumn{2}{|c|}{ Mo } & \multirow[t]{2}{*}{$\mathbf{H}$} & \multirow[t]{2}{*}{$\mathbf{A}$} & \multicolumn{2}{|c|}{ Mo } \\
\hline & & & Index & Cont. & & & Index & Cont. & & & Index & Cont. & & & Index & Cont. \\
\hline \multirow[t]{2}{*}{ Urban } & 43.4 & 40 & 0.17 & 17.3 & 18.0 & 62 & 0.11 & 12.5 & 6.8 & 80 & 0.05 & 8.1 & 1.5 & 100 & 0.01 & 5.0 \\
\hline & & & 0.01 & & & & 0.01 & & & & 0.01 & & & & 0.00 & \\
\hline \multirow[t]{2}{*}{ Rural } & 85.6 & 65 & 0.56 & 82.7 & 69.6 & 74 & 0.52 & 87.5 & 48.9 & 85 & 0.41 & 91.9 & 18.8 & 100 & 0.19 & 95.0 \\
\hline & & & 0.01 & & & & 0.02 & & & & 0.02 & & & & 0.01 & \\
\hline \multirow[t]{2}{*}{ Population } & 68.7 & 59 & 0.40 & 100.0 & 48.9 & 72 & 0.35 & 100.0 & 32.1 & 84 & 0.27 & 100.0 & 11.8 & 100 & 0.12 & 100.0 \\
\hline & & & 0.01 & & & & 0.02 & & & & 0.01 & & & & 0.01 & \\
\hline
\end{tabular}

\section{Panel B: South Sudan}

\begin{tabular}{|c|c|c|c|c|c|c|c|c|c|c|c|c|c|c|c|}
\hline \multirow[t]{3}{*}{ Group } & \multicolumn{3}{|c|}{$\mathbf{k}=\mathbf{1}-$ Union } & \multicolumn{4}{|c|}{$\mathbf{k}=\mathbf{2}$} & \multicolumn{4}{|c|}{$\mathbf{k}=\mathbf{3}$} & \multicolumn{4}{|c|}{$\mathbf{k}=4$ - Intersection } \\
\hline & \multirow[t]{2}{*}{$\mathbf{H}$} & \multicolumn{2}{|l|}{ MO } & \multirow[t]{2}{*}{$\mathbf{H}$} & \multirow[t]{2}{*}{$\mathbf{A}$} & \multicolumn{2}{|c|}{ MO } & \multirow[t]{2}{*}{$\mathbf{H}$} & \multirow[t]{2}{*}{$\mathbf{A}$} & \multicolumn{2}{|c|}{ MO } & \multirow[t]{2}{*}{$\mathbf{H}$} & \multirow[t]{2}{*}{$\mathbf{A}$} & \multicolumn{2}{|c|}{ MO } \\
\hline & & Index & Cont. & & & Index & Cont. & & & Index & Cont. & & & Index & Cont. \\
\hline \multirow[t]{2}{*}{ Urban } & 65.145 & 0.3 & 8.2 & 34.3 & 76 & 0.3 & 6.5 & 14.2 & 81 & 0.1 & 4.5 & 3.5 & 100 & 0.0 & 2.8 \\
\hline & & 0.0 & & & & 0.0 & & & & 0.0 & & & & 0.0 & \\
\hline \multirow[t]{2}{*}{ Rural } & 95.866 & 0.6 & 91.8 & 80.1 & 74 & 0.6 & 93.5 & 54.7 & 86 & 0.5 & 95.5 & 23.5 & 100 & 0.2 & 97.2 \\
\hline & & 0.0 & & & & 0.0 & & & & 0.0 & & & & 0.0 & \\
\hline Population & 90.864 & 0.6 & 100.0 & 72.7 & 74 & $\begin{array}{c}0.5 \\
0.0\end{array}$ & 100.0 & 48.1 & 86 & $\begin{array}{c}0.4 \\
0.0\end{array}$ & 100.0 & 20.3 & 100 & $\begin{array}{c}0.2 \\
0.0\end{array}$ & 100.0 \\
\hline
\end{tabular}


Table A.4.2: Children aged 6 to 14 years

Panel A: Sudan

\begin{tabular}{|c|c|c|c|c|c|c|c|c|c|c|c|c|c|c|c|c|}
\hline \multirow[t]{3}{*}{ Group } & \multicolumn{4}{|c|}{$\mathbf{k}=\mathbf{1}-$ Union } & \multicolumn{4}{|c|}{$\mathbf{k}=\mathbf{2}$} & \multicolumn{4}{|c|}{$\mathbf{k}=\mathbf{3}$} & \multicolumn{4}{|c|}{$k=4$ - Intersection } \\
\hline & \multirow[t]{2}{*}{$\mathbf{H}$} & \multirow[t]{2}{*}{$\mathbf{A}$} & \multicolumn{2}{|c|}{ MO } & \multirow[t]{2}{*}{$\mathbf{H}$} & \multirow[t]{2}{*}{$\mathbf{A}$} & \multicolumn{2}{|c|}{ MO } & \multirow[t]{2}{*}{$\mathbf{H}$} & \multirow[t]{2}{*}{$\mathbf{A}$} & \multicolumn{2}{|c|}{ Mo } & \multirow[t]{2}{*}{$\mathbf{H}$} & \multirow[t]{2}{*}{$\mathbf{A}$} & \multicolumn{2}{|c|}{ Mo } \\
\hline & & & Index & Cont. & & & Index & Cont. & & & Index & Cont. & & & Index & Cont. \\
\hline \multirow[t]{2}{*}{ Urban } & 50.2 & 42 & 0.21 & $\overline{14.9}$ & 23.3 & 62 & 0.14 & $\overline{11.2}$ & 9.6 & 79 & 0.08 & 7.5 & 1.7 & 100 & 0.02 & 3.7 \\
\hline & & & 0.01 & & & & 0.01 & & & & 0.01 & & & & 0.00 & \\
\hline \multirow[t]{2}{*}{ Rural } & 90.0 & 68 & 0.61 & 85.1 & 77.5 & 75 & 0.58 & 88.8 & 56.0 & 85 & 0.48 & 92.5 & 22.3 & 100 & 0.22 & 96.3 \\
\hline & & & 0.01 & & & & 0.02 & & & & 0.02 & & & & 0.01 & \\
\hline \multirow[t]{2}{*}{ Population } & 76.5 & 63 & 0.48 & 100.0 & 59.2 & 74 & 0.44 & 100.0 & 40.4 & 84 & 0.34 & 100.0 & 15.3 & 100 & 0.15 & 100.0 \\
\hline & & & 0.01 & & & & 0.02 & & & & 0.02 & & & & 0.01 & \\
\hline
\end{tabular}

Note: Standard errors are in italics.

\section{Panel B: South Sudan}

\begin{tabular}{|c|c|c|c|c|c|c|c|c|c|c|c|c|c|c|c|c|}
\hline \multirow{3}{*}{ Group } & \multicolumn{4}{|c|}{$\mathbf{k}=1$ - Union } & \multicolumn{4}{|c|}{$\mathbf{k}=\mathbf{2}$} & \multicolumn{4}{|c|}{$\mathbf{k}=3$} & \multicolumn{4}{|c|}{ k=4 - Intersection } \\
\hline & \multirow[t]{2}{*}{$\mathbf{H}$} & \multirow[t]{2}{*}{$\mathbf{A}$} & \multicolumn{2}{|c|}{ Mo } & \multirow[t]{2}{*}{$\mathbf{H}$} & \multirow[t]{2}{*}{ A } & \multicolumn{2}{|c|}{ Mo } & \multirow[t]{2}{*}{$\mathbf{H}$} & \multirow[t]{2}{*}{ A } & \multicolumn{2}{|c|}{ Mo } & \multirow[t]{2}{*}{$\mathbf{H}$} & \multirow[t]{2}{*}{$\mathbf{A}$} & \multicolumn{2}{|c|}{ Mo } \\
\hline & & & Index & Cont. & & & Index & Cont. & & & Index & Cont. & & & Index & Cont. \\
\hline \multirow[t]{2}{*}{ Urban } & 60.0 & 45 & 0.27 & 7.2 & 30.7 & 64.6 & 0.20 & 5.7 & 14.2 & 81.2 & 0.12 & 4.5 & 3.8 & 100 & 0.04 & 3.3 \\
\hline & & & 0.02 & & & & 0.02 & & & & 0.02 & & & & 0.01 & \\
\hline \multirow[t]{2}{*}{ Rural } & 91.9 & 65 & 0.59 & 92.8 & 76.6 & 72.6 & 0.56 & 94.3 & 54.7 & 85.7 & 0.47 & 95.5 & 18.5 & 100 & 0.19 & 96.7 \\
\hline & & & 0.01 & & & & 0.02 & & & & 0.03 & & & & 0.01 & \\
\hline \multirow[t]{2}{*}{ Population } & 87.3 & 63 & 0.55 & 100.0 & 69.9 & 72.1 & 0.50 & 100.0 & 48.1 & 85.5 & 0.41 & 100.0 & 16.4 & 100 & 0.16 & 100.0 \\
\hline & & & 0.01 & & & & 0.01 & & & & 0.02 & & & & 0.01 & \\
\hline
\end{tabular}

Note: Standard errors are in italics. 


\section{References}

Alkire, S.and Foster, J. (2011). Counting and multidimensional poverty measurement. Journal of Public Economics, 95(7): 476-487.

Alkire, S., Foster, J., Seth, S., Santos, M.E., Roche, J.M. and Ballon, P., 2015. Multidimensional poverty measurement and analysis. Oxford University Press, USA.

Alkire, S. and Foster, J. (2016). Dimensional and distributional contributions to multidimensional poverty. OPHI Working Paper 100, University of Oxford.

Araar, A. and Duclos, J.-Y. (2007). DASP: Distributive analysis stata package. PEP, CIRPÉE and World Bank, Université Laval.

Asselin, L. M. (2009). Analysis of multidimensional poverty: Theory and case studies (Vol. 7). Springer.

Davidson, R. and Duclos, J.-Y. (2000). Statistical inference for stochastic dominance and for the measurement of poverty and inequality. Econometrica, 68(6):1435-64.

Deaton, A. and Zaidi, S. (2002). Guidelines for constructing consumption aggregates for welfare analysis. Working Paper LSM-135, World Bank.

Duclos, J.-Y., Sahn, D. E., and Younger, S. D. (2006). Robust multimensional poverty comparison. Economic Journal, 113:943-968.

Duclos, J.-Y. (2011). UNDP's multidimensional poverty index. Working document I-11, FERDI.

Foster, J. E., Greer, J., and Thorbecke, E. (1984). A class of decomposable poverty measures. Econometrica, 52:761-766.

Foster, J. and Sen, A. (1997). On Economic Inequality after a Quarter Century. Oxford, Clarendon Press.

Foster, J. (1984). On economic poverty: A survey of aggregate measures. In Advances in Econometrics, volume 3, pages 215-251. Connecticut: JAI Press.

Government of Sudan (2012). Sudan's interim poverty reduction strategy paper. Technical report.

Greenacre, M. and Blasius, J. (2006). Multiple Correspondence Analysis and Related Methods. Statistics in the Social and Behavioral Sciences Series. CRC Press. 
Haughton, J. and Khandker, S. R. (2009). Handbook on poverty and inequality. The World Bank, Washington D.C.

U.N. High-Level Panel of Eminent Persons on the post-2015 Development Agenda. (2013). A New Global Partnership: Eradicate Poverty and Transform Economies through Sustainable Development. Report to U.N. Secretary-General Ban KiMoon. < http://www.post2015hlp.org/the-report/>

UNDP (1990-2014). Human Development Report 1990 - 2014, UNDP, New York.

World Bank (2005). World Development Report 2006: Equity and Development. World Bank, Washington.

Zheng, B. (1997). Aggregate poverty measures. Journal of Economic Surveys, 11(2):123-62. 